\title{
The past 500 years of rock art at Nawarla Gabarnmang, central-western Arnhem Land
}

\author{
Robert Gunn, Bruno David, Jean-Jacques Delannoy \\ and Margaret Katherine
}

\section{Introduction}

The Arnhem Land plateau in northern Australia contains a particularly rich rock art assemblage. The area has a small number of large rockshelters with numerous and extensive suites of superimposed motifs (c. 2 per cent of 630 recorded shelters have $>200$ images). Studies of the rock art of Arnhem Land have primarily been concerned with attempting to understand the age of the art, with particular interest on the Pleistocene to mid-Holocene periods (Chaloupka 1977, 1984, 1985, 1993; Chippindale and Taçon 1993; Haskovec 1992; Lewis 1998; Taçon and Chippindale 1994). Most of these efforts have largely relied on interpretations of styles and their respective patterns of superimposition. Taçon (e.g. 1987, 1989a, 1989b, 1992) has written extensively on X-ray rock art from the northern perimeter of the plateau, and his work on 'recent' period art remains the most important study on this subject. The production of X-ray art has also been shown to have been popular during the European-contact period of the past 200 years or so (Chaloupka 1993; May et al. 2010; Wesley 2013). The most detailed study of rock art in the late Holocene period is the extensive radiocarbon dating of beeswax figures by Nelson et al. (2000), most of which fall within the past 500 years (but see Bednarik 2001).

Taçon (1989b:318) has noted, 'The most recent period of rock painting in western Arnhem Land ... was one of great diversity and elaboration. It differs from earlier periods in terms of subject matter, form, use of colour and symbolic content. It is this art that is still very important to Aboriginal people'. He found that, other than X-ray art, solid or stroke infill were common conventions that differed from X-ray only in their pattern of infill and that, in opposition to their Kunwinjku neighbours to the east (Taylor 1996:12), the 'Aboriginal people [of western Arnhem Land] argue that [monochrome paintings] depict "dead" or "cooked" beings while x-ray paintings depict living creatures' (Taçon 1989b:320). He also suggested that X-ray art reached its 'full potential' during the Freshwater Period of less than 3000 years ago (Taçon 1989b:330).

Other recent forms of art that Taçon (1989b:320-324) identified from western Arnhem Land are:

- Stick-figures, both static and active, depicting common activities (hunting, domestic, ceremonial or warfare).

- Hand stencils - some with finely painted patterned infill - and stencils of human and animal feet. 
- Painted sacred symbols and other geometric shapes, lines or patterns.

- Appliqué images in pressed beeswax.

- European-contact images (boats, horses, rifles, cattle, etc.).

- Sorcery images.

Overall, Taçon (1992:210-211) found that Aboriginal peoples of western Arnhem Land recognise five classes of rock art:

- 'Sacred Beings': images of Dreaming Beings who put themselves onto the rock face.

- 'Dreaming' paintings: mostly related to Dreaming stories or beliefs.

- 'Mimi': all older (predominantly red) paintings are said by local Aboriginal people to be produced by Spirit-Beings who dwell in the rock, and which some archaeologists assume to be $>6000$ years old (Taçon 1993:114).

- 'Sorcery' paintings: 'paintings used for revenge or to inflict harm, but these were relatively rare' (Taçon 1991:211). Berndt and Berndt (1977:323) viewed sorcery paintings of deformed or skewered figures, which were painted to cause death or illness to the victim, as a practice of social constraint. Chaloupka (1993:207) considered the majority of sorcery paintings to have been produced during the recent, European-contact period.

- 'Casual' paintings: including some hand stencils, recent stick-figures and European-contact motifs.

These five classes of rock art are essentially the same as those identified by Chaloupka (1993:87) who further includes the category 'bim bawarde garruy' (petroglyphs made in the 'Ancestral past').

In a study of regionalism in the rock art of western Arnhem Land, Taçon defined a Jawoyn substyle (that Chaloupka [1984:21] had first noted to be distinctive) as being:

composed primarily of red-and-white bichrome $\mathrm{x}$-ray paintings, with some red-and-yellow, as well as solid red or solid white images. Some yellow solid infill figures can be found but they are much rarer. Depictions of $\mathrm{x}$-ray and solid/stroke infill macropods and humans predominate. Hand stencils are found but painted hand or hand-and-arm stencils, typical of areas to the north, are not. Small, delicate strokes are characteristic of outlines and infill. Very small numbers of other forms, such as static stick figures, subjects and motifs are found at Jawoyn sites in comparison to those associated with other language groups (Taçon 1993:115).

In contrast to more northern sub-styles, where fish are the predominant faunal taxa depicted, the Jawoyn sub-style of X-ray art was said to be dominated by paintings of macropods (Taçon 1993:117). This contrast between fish-dominated art sites of the north and macropod-dominated sites of the south also highlights a substantial difference between the beliefs of the Jawoyn and those of their northern neighbours. This is well exemplified by an emphasis on the macropod Dreaming Beings Gupu and Barrk (Gunn 1992:180) in the south versus fish and 'brightness' with a visual reference to the Rainbow Serpent in the north (Taçon 1992:197). A further significant difference is the predominant use of red and white for bichrome paintings by the Jawoyn, while those groups to the north utilised a greater variety of colour combinations (Taçon 1989:125).

In this chapter, the relative chronology of motifs at the highly decorated rockshelter of Nawarla Gabarnmang in Jawoyn lands of the Arnhem Land plateau (see Figure 1.1) is examined, to test and refine the findings of these previous studies. Through patterns of superimposition and absolute ages that enable particular layers of art to be dated, the range of depicted styles and subjects that can be shown to be less than c. 500 years old within the shelter are illustrated and discussed. 


\section{Nawarla Gabarnmang}

Nawarla Gabarnmang is a large sandstone shelter (c. $25 \times 15 \times 2 \mathrm{~m}$ ) with a horizontal ceiling supported by a number of freestanding pillars (Figures 12.1 and 12.2). The pillars divide the ceiling into a series of panels, most of which have been decorated with art (Figure 12.3). Many of the central pillars have also been decorated with both recent paintings and, in some cases, very old petroglyphs (cupules and abradings). Occupation at the site has been dated to $>45,000$ cal BP (David et al. 2011; Geneste et al. 2010). The interior of the shelter has been substantially modified through the removal of pillars and the collapse or removal of layers of rock ceiling to produce a large, central occupation area (Delannoy et al. 2013; see Chapter 10).

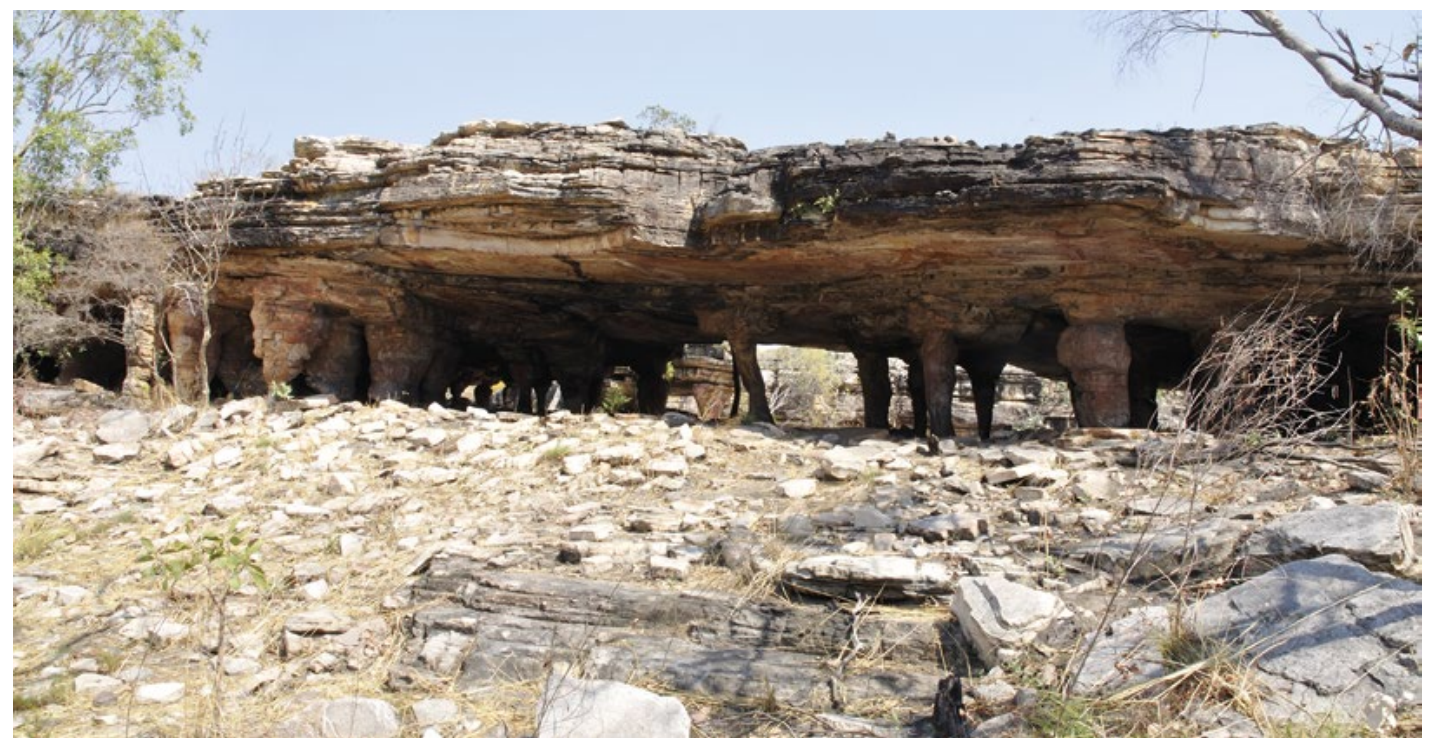

Figure 12.1 Nawarla Gabarnmang shelter from the northwest.

Source: Photograph by Robert Gunn.

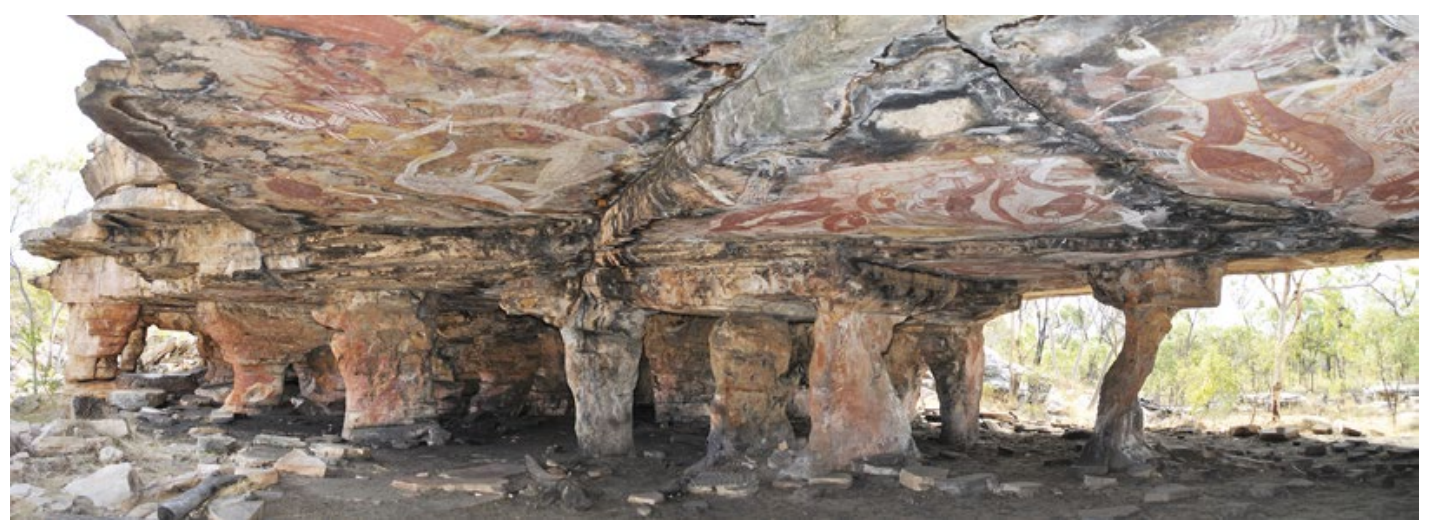

Figure 12.2 Interior of shelter showing the highly decorated ceiling.

Source: Photograph by Robert Gunn.

Throughout this chapter, the radiocarbon dates undertaken directly on rock art are calibrated as cal $\mathrm{AD}$ rather than cal $\mathrm{BP}$ ages in order to facilitate correlations with European-contact period historical events and documentary records. Within Nawarla Gabarnmang, the individual ceiling panels with art have been allocated unique codes for ease of identification (Figure 12.3). Two beeswax figures on Panel F1 have each been radiocarbon dated to the period 1433-1631 cal $\mathrm{AD}$, with another two beeswax figures on nearby Panels $\mathrm{H}$ and $\mathrm{K} 4$ dating to the period 
1658-1952 cal AD (Table 12.1). The two beeswax figures on Panel F1, and that on Panel H, are superimposed by paintings. The beeswax figure on panel K4 superimposes yellow paintings, but it is not itself superimposed by any art. Panel J1 has a fifth beeswax figure also dating to c. 400 cal BP, but it is still being analysed and thus does not feature in this chapter. Panel D has a painted motif interpreted as a representation of a horse. As horses were unknown on the plateau before $1845 \mathrm{AD}$, the motifs that overlie the horse image must be more recent (Gunn et al. 2012; see also Chapter 9). The overlying motifs of the individual panels are discussed below prior to a general comment on the nature of the more recent art found in the shelter.

Table 12.1 Radiocarbon dates on beeswax rock art.

\begin{tabular}{|l|c|c|c|c|}
\hline Laboratory code & Panel & Image \# & ${ }^{14}$ C Age (BP) & Calibrated age AD (95.4\% probability) \\
\hline Wk-26414 & F1 & 28 & $406 \pm 30$ & $1430-1530$ \\
& & & & $1570-1630$ \\
\hline Wk-26416 & F1 & 27 & $383 \pm 30$ & $1440-1530$ \\
& & & & $1550-1640$ \\
\hline Wk-28101 & H & 122 & $173 \pm 30$ & $1650-1700$ \\
& & & & $1720-1820$ \\
& & & & $1830-1880$ \\
& K4 & 100 & $153 \pm 30$ & $>1910$ \\
\hline Wk-26418 & & & & $>1660-1890$ \\
& & & \\
\hline
\end{tabular}

Calibrations undertaken using 0xCal v4.2.4 (Bronk Ramsay 2013), IntCal13 (Reimer et al. 2013). For full sample details, see Gunn et al. (2012).

Source: Authors' data.

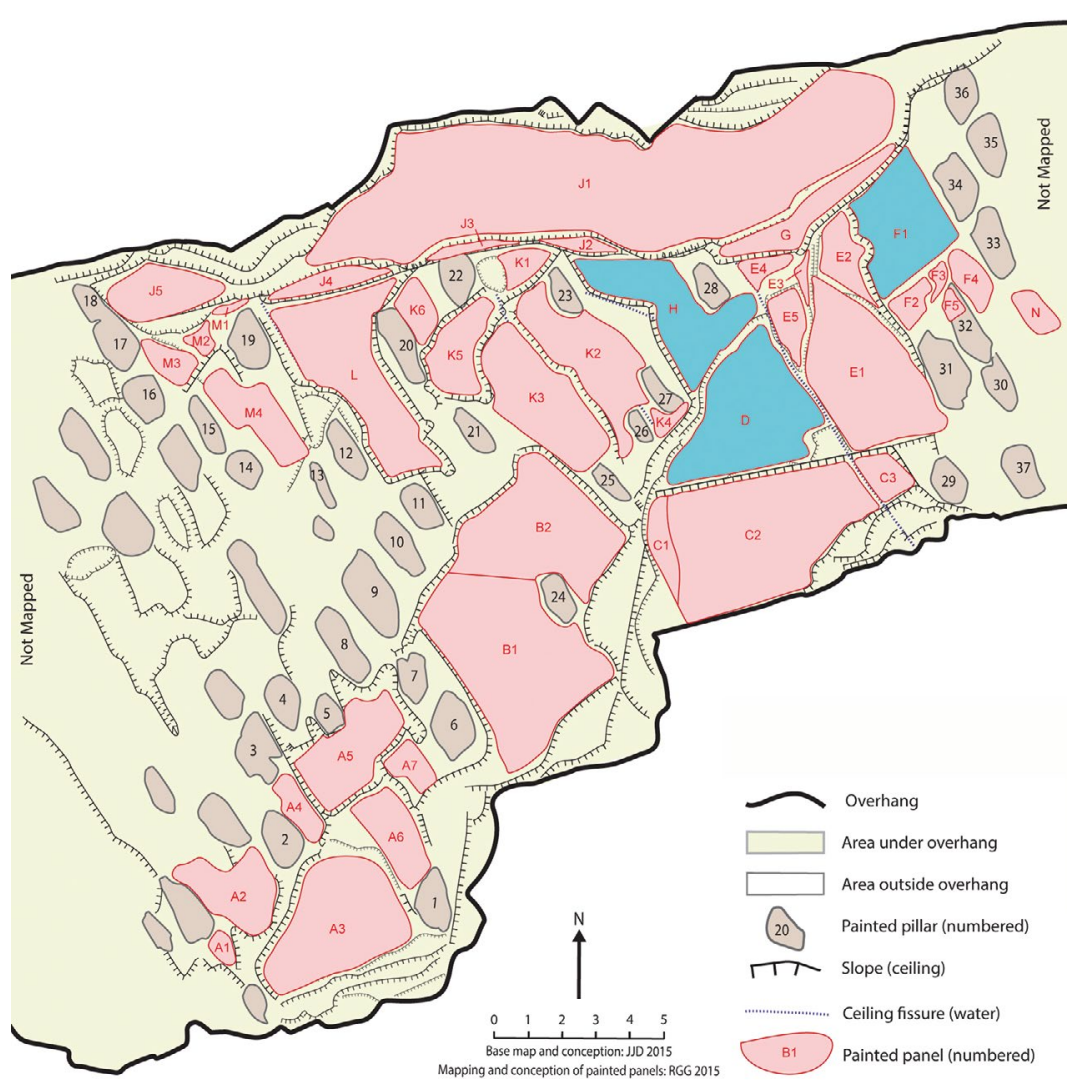

Figure 12.3 Plan showing location of the ceiling art panels. Panels D, F1 and $\mathrm{H}$ are highlighted. Source: Illustration by Jean-Jacques Delannoy and Robert Gunn. 


\section{Panel F1}

Panel F1 is one of the largest art panels in the shelter, $3.8 \times 2.7 \mathrm{~m}$ in size and generally rectangular in shape (Figure 12.4). It contains 126 identified images widely distributed across the panel (Figure 12.5). The only visually prominent motif is an X-ray snake $(94 \times 48 \mathrm{~cm})$ placed in the very centre of the panel. Other prominent images on the panel are the smaller of a pair of white macropods with red linear infill, and three female figures in white. Some of the many images on this panel appear to be among the most recent in the shelter in that they appear very 'fresh' relative to the other paintings, include fragile white pigments and occur as, or adjacent to, the top layer in the pattern of superimposition. Yet, Panel F1 has none of the painted X-ray fish that dominate the other large panels (Panels D, E1 and H; see Gunn et al. 2012; Chapter 11, this volume).

Panel F1 has at least 35 layers of superimpositions involving all of the 126 identified images (Gunn 2016). A Harris Matrix was produced relating all instances of superimposition (Figure 12.6). The Harris Matrix was then sorted into layers, each layer seen as representing an artistic episode of relatively short duration (Figure 12.7). In this sorting, images were allocated to particular layers on the basis of their relative location in the superimposition sequence coupled with common artistic traits - colour, form, infill, state of preservation, etc. The layers were then grouped into six broad phases by similarities in artistic traits between adjacent layers (Table 12.1).

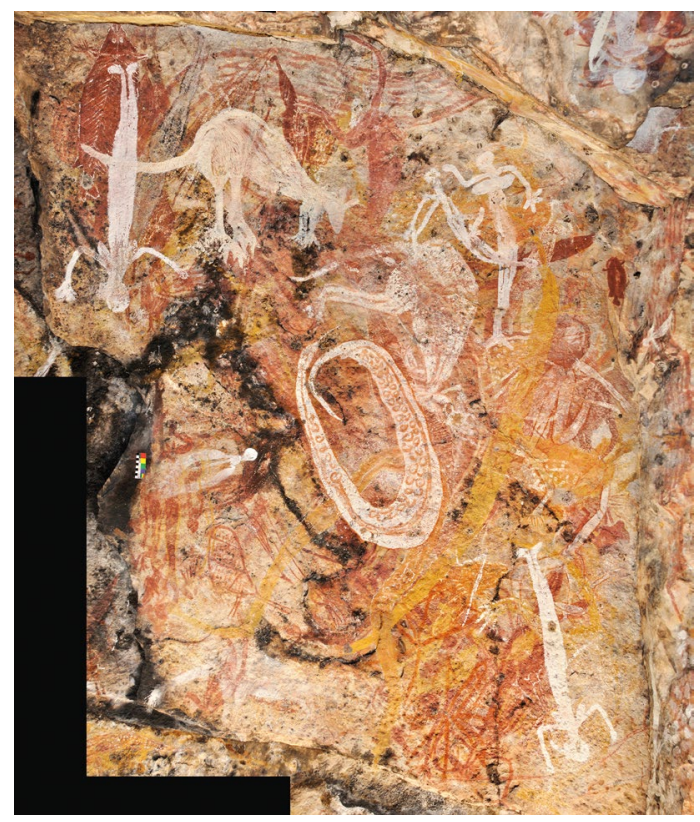

Figure 12.4 Photomosaic of Panel F1.

Source: Photographs by Robert Gunn.

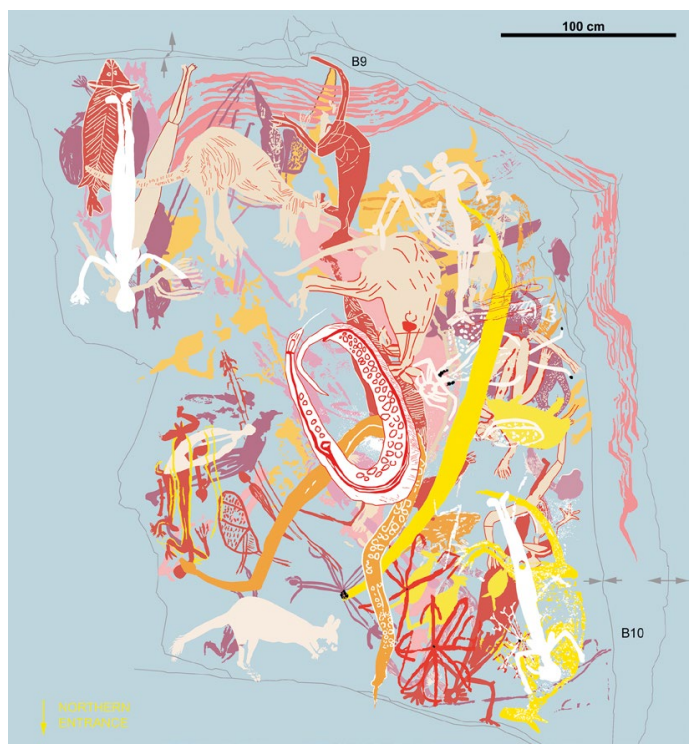

Figure 12.5 Tracing from the photomosaic of the Panel F1 art (colours approximate).

Source: Photo-tracing by Robert Gunn. 


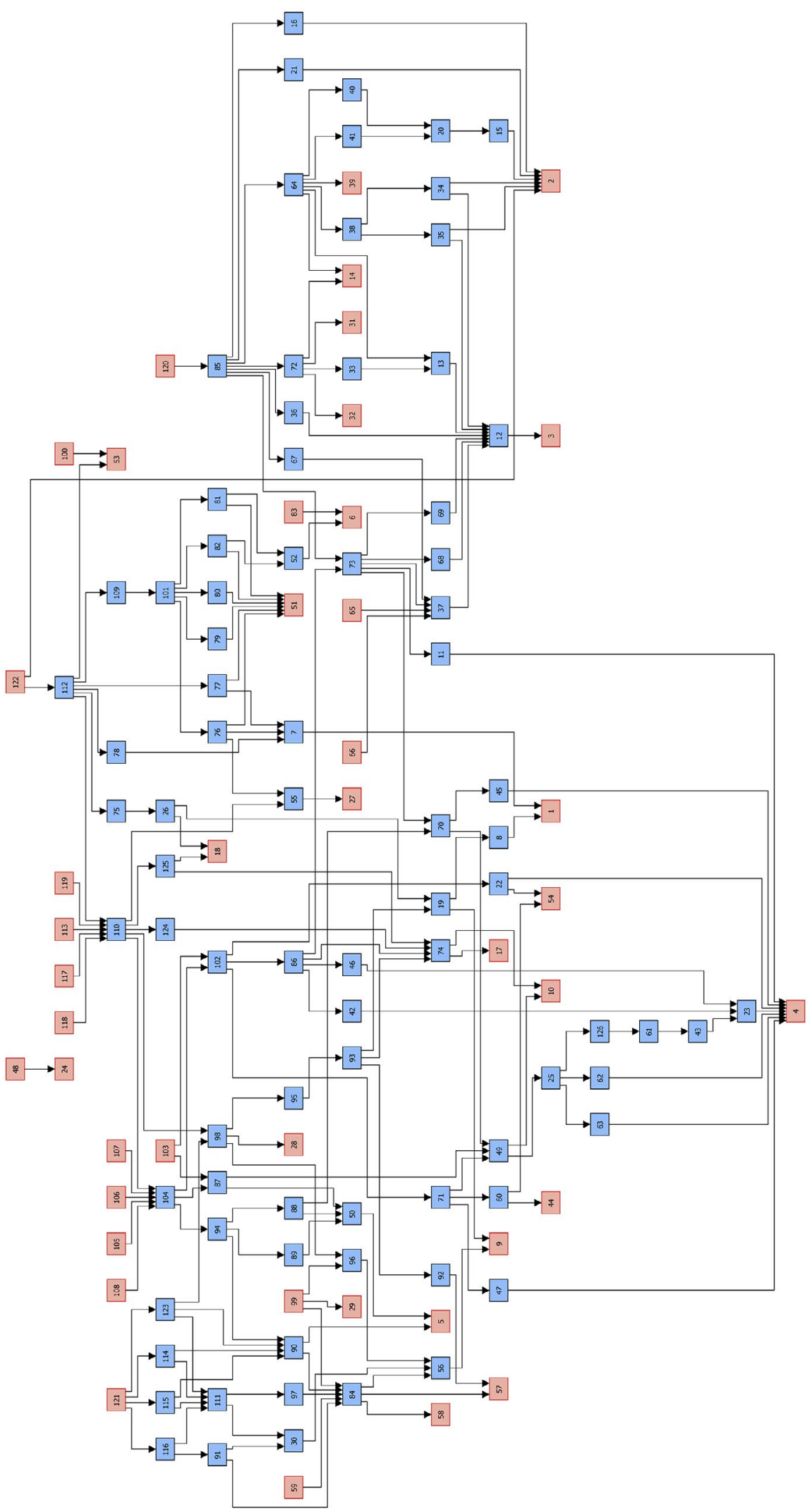

Figure 12.6 Harris Matrix of the Panel F1 superimpositions.

Red boxes = images at beginning or end of a superimposition sequence; blue boxes = images within a superimposition sequence. Source: Illustration by Robert Gunn. 

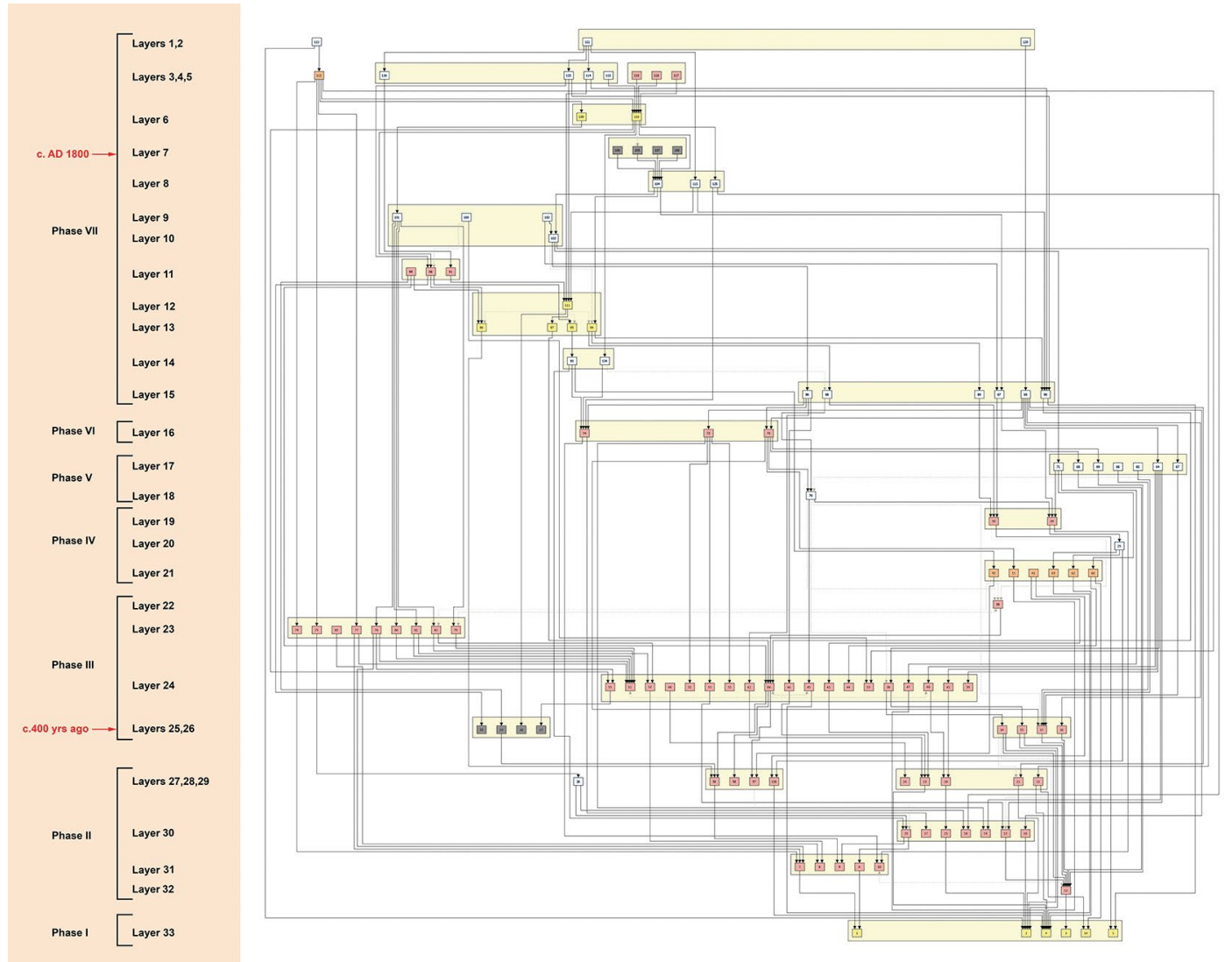

Figure 12.7 Interpretation of the Panel F1 Harris Matrix, grouping the motifs into contemporaneous layers on the basis of stylistic attributes and preservation.

Source: Illustration by Robert Gunn.

Beeswax pellets made before the painting were incorporated in four painted images, and one was added to a fifth image after it was painted. The pellets, each allocated an individual image number, are in two spatially distinct groups: pellets F-27 to F-30, associated with paintings F-55, F-91, F-98 and F-99; and pellets F-105 to F-108, associated with painting F-104. Pellets F-27 to F-30 are individual beeswax dots making the centres of red-painted radial designs (Figure 12.8). Pellets F-105 to F-108 are elaborations on a white-painted female figure (Figure 12.9). Radiocarbon dates on pellets F-27 and F-28 each calibrate within the period 1430-1640 cal AD (Table 12.1). As all four of the pellets within this group (F-27 to F-30) are in similar states of preservation, located within $85 \mathrm{~cm}$ of each other and positioned at the same level in the pattern of superimposition, it is likely that they were applied during a single artistic event. Pellets F-28 to F-30 are all small and central to red-painted radial designs, while pellet F-27 is larger and underlies a design in a darker shade of red and a yellow snake. Pellet F-28 also underlies the radial design, indicating that it was applied before the red radiating lines were painted; its relationship to an apparently underlying yellow flying-fox remains unclear. 


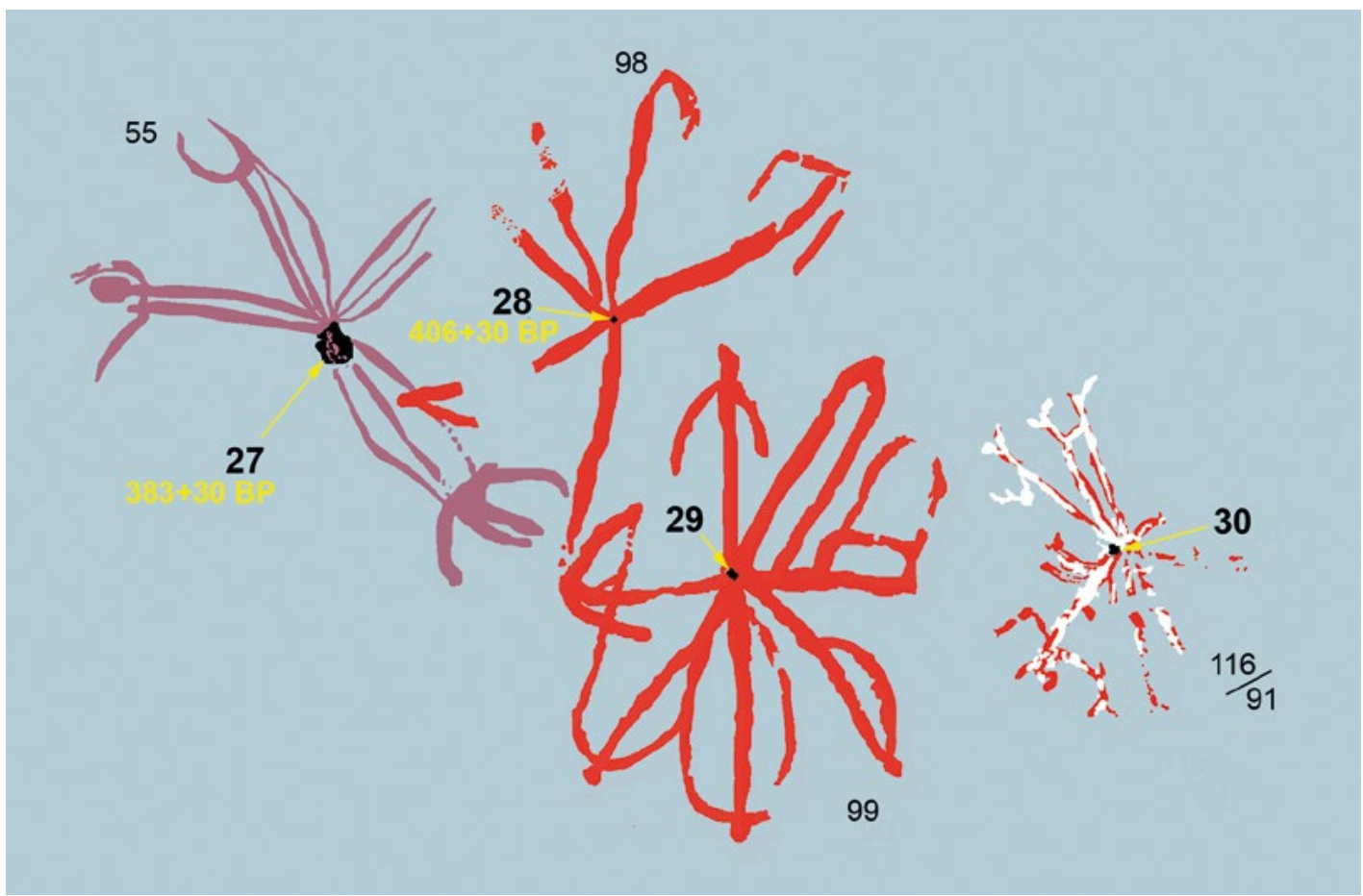

Figure 12.8 Beeswax pellets F-27 to F-30 showing overlying radial designs.

The two dated pellets were radiocarbon dated to 1430-1640 cal AD.

Source: Photo-tracing by Robert Gunn.
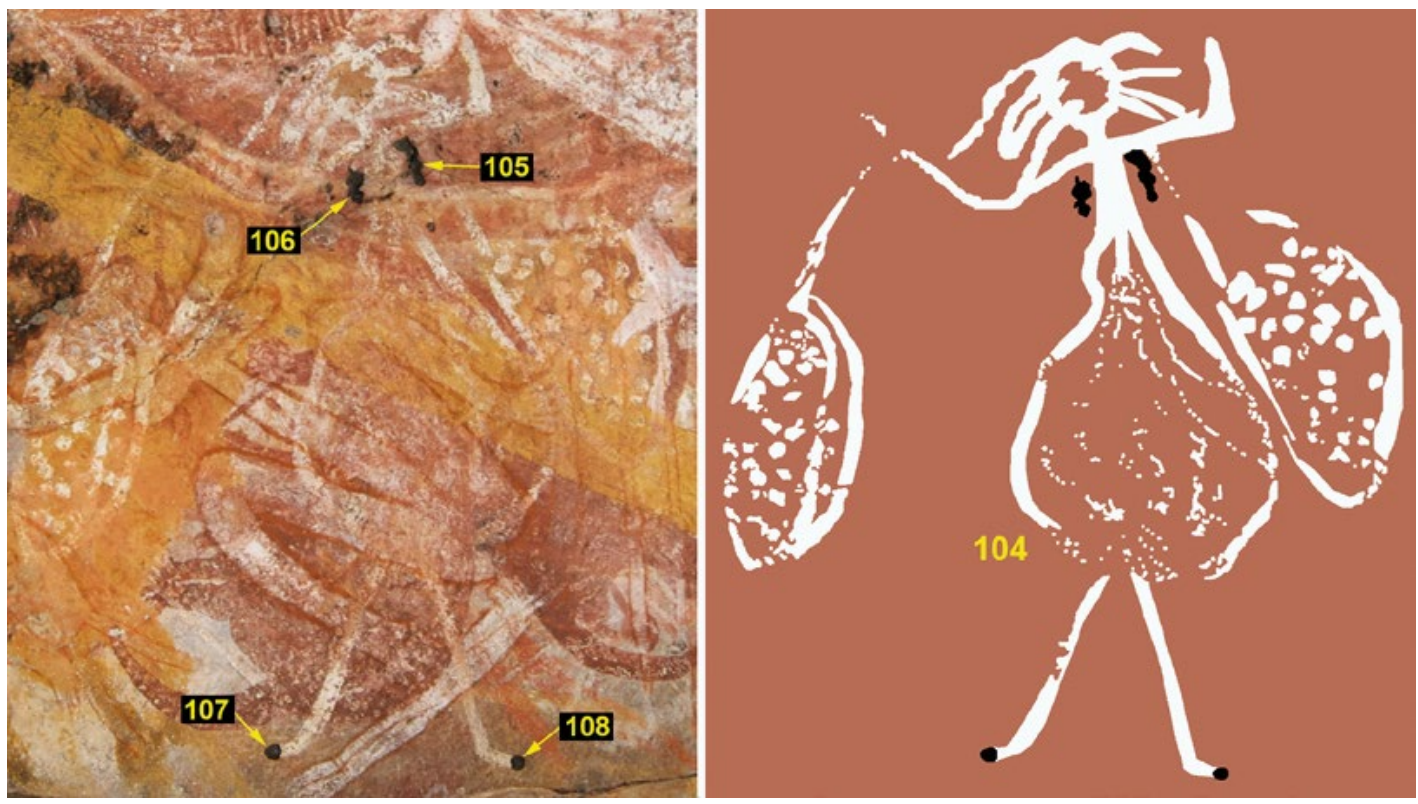

Figure 12.9 Beeswax Pellets F-105 to F-108 overlying painting F-104.

Source: Photograph and photo-tracing by Robert Gunn. 
Most of the art that underlie these dated pellets consists of poorly preserved fragments in monochrome pigment. The exceptions are a poorly preserved but intact long monochrome snake that encircles the panel, three paintings in red with fine-line white, hatched infill- and a yellow fragment partially outlined in red. These four bichrome paintings indicate that bichrome art was practised sometime before c. 400-500 years ago, as they underlie the beeswax pellets dated to that age.

The beeswax pellets F-105 to F-108 are undated. We know that, with time, beeswax pellets deteriorate from a shiny black to a crazed grey (Nelson 2000). Although these pellets are in comparable positioning under the well protected shelter, they are darker in colour than the beeswax of pellets F-27 to F-30 and lack the crazing of the c. 400-500-year-old pellets. This suggests that pellets F-105 to F-108 are younger than the dated pellets F-27 and F-28. Pellets F-105 to F-108 are in a comparable state of preservation to a beeswax figure on Panel K4 nearby (Figure 12.10), where a radiocarbon date calibrated to $1633-1953 \mathrm{cal}$ AD has been obtained. We conclude that these two sets of beeswax pellets are likely to be of similar age,

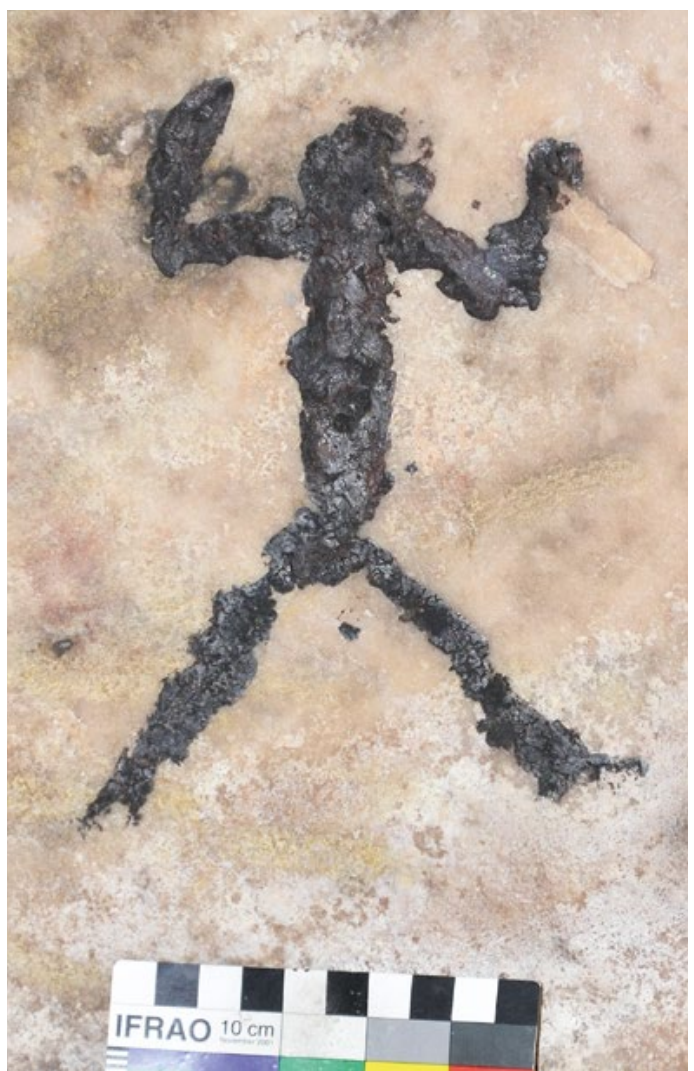

Figure 12.10 Beeswax figure dated to 1660$>1900$ cal AD on Panel K4.

Source: Photograph by Robert Gunn. within the past 400 years.

These radiocarbon dates place four of the art phases on Panel F1 Phases III-VI in the period after $1430 \mathrm{cal}$ AD. These four phases contain 97 images, or over three-quarters of the visible art of Panel F1. The 17 images in the most recent layer were all made after c. $1650 \mathrm{cal} \mathrm{AD}$, as indicated by the extrapolated ages of pellets F-105 to F-108 (Table 12.2).

Table 12.2 Summary of the Panel F1 art phases.

\begin{tabular}{|l|l|l|l|l|l|}
\hline Panel F1 phase & \# of layers & \# of images & Techniques & Colours & Major motifs \\
\hline VIb & 15 & 40 & paintings & $\begin{array}{l}\text { white, white+red, } \\
\text { orange+white, } \\
\text { yellow+red, } \\
\text { yellow, red, black }\end{array}$ & $\begin{array}{l}\text { Bichrome snakes; } \\
\text { Solid white anthropomorphs (females); } \\
\text { Outline+infill weapons }\end{array}$ \\
\hline 1660->1900 cal AD (age of beeswax pellets extrapolated from Panel K4) \\
\hline Vla & \multicolumn{7}{|l|l|l|l|}{$\begin{array}{l}\text { paintings, } \\
\text { stencil }\end{array}$} & $\begin{array}{l}\text { white, yellow, } \\
\text { red, white+red }\end{array}$ & $\begin{array}{l}\text { Solid white anthropomorphs (male and } \\
\text { female) and macropod; } \\
\text { frea of sprayed pigment; } \\
\text { Outline+infill radial designs, fish and bags; } \\
\text { Solid yellow flying fox, echidna and macropod; } \\
\text { Bichrome 'Jawoyn Ladies' and macropod }\end{array}$ \\
\hline V & 1 & 3 & paintings & white+red & $\begin{array}{l}\text { Bichrome anthropomorph (female), X-ray } \\
\text { macropod and fish }\end{array}$ \\
\hline
\end{tabular}




\begin{tabular}{|l|l|l|l|l|l|}
\hline Panel F1 phase & \# of layers & \# of images & Techniques & Colours & Major motifs \\
\hline IV & 5 & 17 & paintings & $\begin{array}{l}\text { white, white+red, } \\
\text { red, orange }\end{array}$ & $\begin{array}{l}\text { Bichrome anthropomorphs, Solid white } \\
\text { anthropomorph (females); } \\
\text { Outline+infill snake and fish; } \\
\text { Solid red possum; } \\
\text { Solid orange fish and echidna }\end{array}$ \\
\hline III & 7 & 37 & paintings & red & $\begin{array}{l}\text { Red solid or outline+infill fish, } \\
\text { anthropomorph, weapons and bags }\end{array}$ \\
\hline $\mathbf{1 4 3 0 - 1 6 4 0 ~ c a l ~ A D ~ ( d a t e d ~ b e e s w a x ~ p e l l e t s ) ~}$ & & paintings & red, red+white & $\begin{array}{l}\text { Striped red snake; } \\
\text { Solid red anthropomorph with fine white- } \\
\text { line infill; } \\
\text { Fragments of pigment art }\end{array}$ \\
\hline II & 6 & 23 & paintings & $\begin{array}{l}\text { yellow, } \\
\text { yellow+red }\end{array}$ & $\begin{array}{l}\text { Mainly yellow fragments } \\
\text { (2 solid and solid+outline animals) }\end{array}$ \\
\hline
\end{tabular}

Note that for bichrome paintings, the base colour is listed first and the later, additional colour second. For example, white+red is a white solid silhouette with red outline and/or infill.

Source: Authors' data.

Tabulation of motif types by phase for Panel F1 suggests that little change in artistic conventions took place over the past 400-500 years (Table 12.3). During that same period, there appears to have been a seven-fold increase in the use of white pigment and white-based bichrome painting, correlating with both a relative and an absolute decrease in the number of red and red-based bichrome motifs (Table 12.4). Panel F1 is a horizontal ceiling panel that is well protected from the elements, and beyond reach of passing animals. Consequently, it is unlikely that the observed increase in white pigment is simply a function of taphonomic factors, nor can it explain the absolute decline in the use of red pigment.

Table 12.3 Panel F1 motifs by art phase.

\begin{tabular}{|c|c|c|c|c|c|c|c|c|c|c|c|c|c|}
\hline \multirow{2}{*}{$\begin{array}{l}\text { Panel F1 } \\
\text { phase }\end{array}$} & \multicolumn{12}{|c|}{ Motif } & \multirow{2}{*}{$\begin{array}{c}\text { Total \# of } \\
\text { images }\end{array}$} \\
\hline & 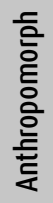 & $\frac{\mathscr{\mathscr { V }}}{\stackrel{0}{\check{n}}}$ & 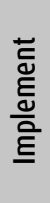 & 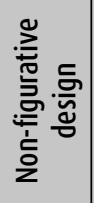 & 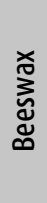 & 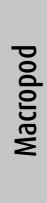 & $\underline{\underline{\underline{n}}}$ & 䔰 & 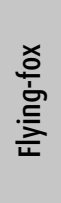 & క్ & $\frac{\text { Ф }}{\frac{\Xi}{0}}$ & 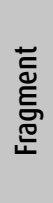 & \\
\hline $\mathrm{VIb}$ & 2 & 3 & 3 & 4 & 4 & & & & & & 1 & & 17 \\
\hline \multicolumn{14}{|c|}{ 1660->1900 cal AD (age of beeswax pellets extrapolated from Panel K4) } \\
\hline Vla & 6 & & 1 & 6 & & 4 & 1 & 1 & 3 & & 1 & & 23 \\
\hline V & & & & & & 1 & 1 & & & & 1 & & 3 \\
\hline IV & 2 & 1 & & 1 & & & 2 & 1 & & 2 & 6 & 2 & 17 \\
\hline III & 6 & & 8 & 1 & 4 & 1 & 12 & & & & 4 & 1 & 37 \\
\hline \multicolumn{14}{|c|}{ 1430-1640 cal AD (dated beeswax pellets) } \\
\hline II & 3 & 1 & & 3 & & & & & & & 2 & 14 & 23 \\
\hline I & & & & & & & & & & & 2 & 4 & 6 \\
\hline Total & 19 & 5 & 12 & 16 & 8 & 6 & 16 & 2 & 3 & 2 & 16 & 21 & 126 \\
\hline
\end{tabular}

Source: Authors' data. 
Table 12.4 Panel F1 colours by art phase.

\begin{tabular}{|l|c|c|c|c|c|c|c|c|c|c|}
\hline \multirow{2}{*}{$\begin{array}{l}\text { Panel F1 } \\
\text { phase }\end{array}$} & \multicolumn{7}{|c|}{ Colour } & Total \# of \\
images
\end{tabular}

Source: Authors' data.

\section{Panel H}

Panel $\mathrm{H}$ is a large, elongated panel forming a rough T-shape, $4.0 \times 2.9 \mathrm{~m}$ long along its two axes (Figure 12.11). It contains 132 widely distributed images, but the panel is visually dominated by two large polychrome X-ray barramundi $(180 \times 84 \mathrm{~cm}$ and $143 \times 53 \mathrm{~cm}$ respectively $)$ that may hide many underlying images. Panel $\mathrm{H}$ has at least 21 layers of superimposition involving all except for two of its 132 images (Images H-7 and H-116). Interpretation of the Harris Matrix (Figure 12.12) suggests at least six phases of art production on this panel (Table 12.5; Figure 12.13). The two outlying motifs were included in the Harris Matrix by allocating them to particular layers following artist traits that matched those of other nearby motifs.

Table 12.5 Summary of the Panel $\mathrm{H}$ art phases.

\begin{tabular}{|c|c|c|c|c|c|}
\hline Panel H phase & \# of layers & \# of images & Techniques & Colours & Major motifs \\
\hline VI & 1 & 2 & painting & white+red+black & Fish in polychrome X-ray \\
\hline $\mathrm{Vb}$ & 6 & 15 & $\begin{array}{l}\text { painting, } \\
\text { appliqué }\end{array}$ & $\begin{array}{l}\text { white, white+red, } \\
\text { red, black }\end{array}$ & $\begin{array}{l}\text { White solid anthropomorphs } \\
\text { and fish; } \\
\text { Red linear anthropomorph; } \\
\text { Solid white+red outline+infill } \\
\text { anthropomorphs and macropods }\end{array}$ \\
\hline \multicolumn{6}{|c|}{ 1660->1900 cal AD (dated beeswax anthropomorph) } \\
\hline Va & 2 & 22 & & white & $\begin{array}{l}\text { Solid white+red outline+infill } \\
\text { anthropomorphs and turtle; } \\
\text { White outline+infill anthropomorphs, } \\
\text { emu, dillybag and digging stick }\end{array}$ \\
\hline IV & 2 & 17 & $\begin{array}{l}\text { painting, } \\
\text { stencils }\end{array}$ & white, yellow & $\begin{array}{l}\text { White hand stencils; } \\
\text { White-painted outline+infill non- } \\
\text { figurative designs and macropod; } \\
\text { Yellow fragments of pigment art }\end{array}$ \\
\hline III & 2 & 10 & painting & red, red+white & $\begin{array}{l}\text { Solid red macropods and turtle; } \\
\text { Solid red+white outline+infill } \\
\text { macropod and snake }\end{array}$ \\
\hline
\end{tabular}




\begin{tabular}{|l|l|l|l|l|l|}
\hline Panel H phase & \# of layers & \# of images & Techniques & Colours & Major motifs \\
\hline II & 7 & 46 & $\begin{array}{l}\text { painting, } \\
\text { stencils }\end{array}$ & red, white, yellow & $\begin{array}{l}\text { White hand stencils; } \\
\text { White-painted arc design; } \\
\text { Red outline+striped infill } \\
\text { anthropomorph and macropod; } \\
\text { Yellow outline+infill bird }\end{array}$ \\
\hline I & 1 & 20 & painting & red & $\begin{array}{l}\text { Solid red animals and fragments of } \\
\text { red, yellow and white pigment art }\end{array}$ \\
\hline
\end{tabular}

Source: Authors' data.

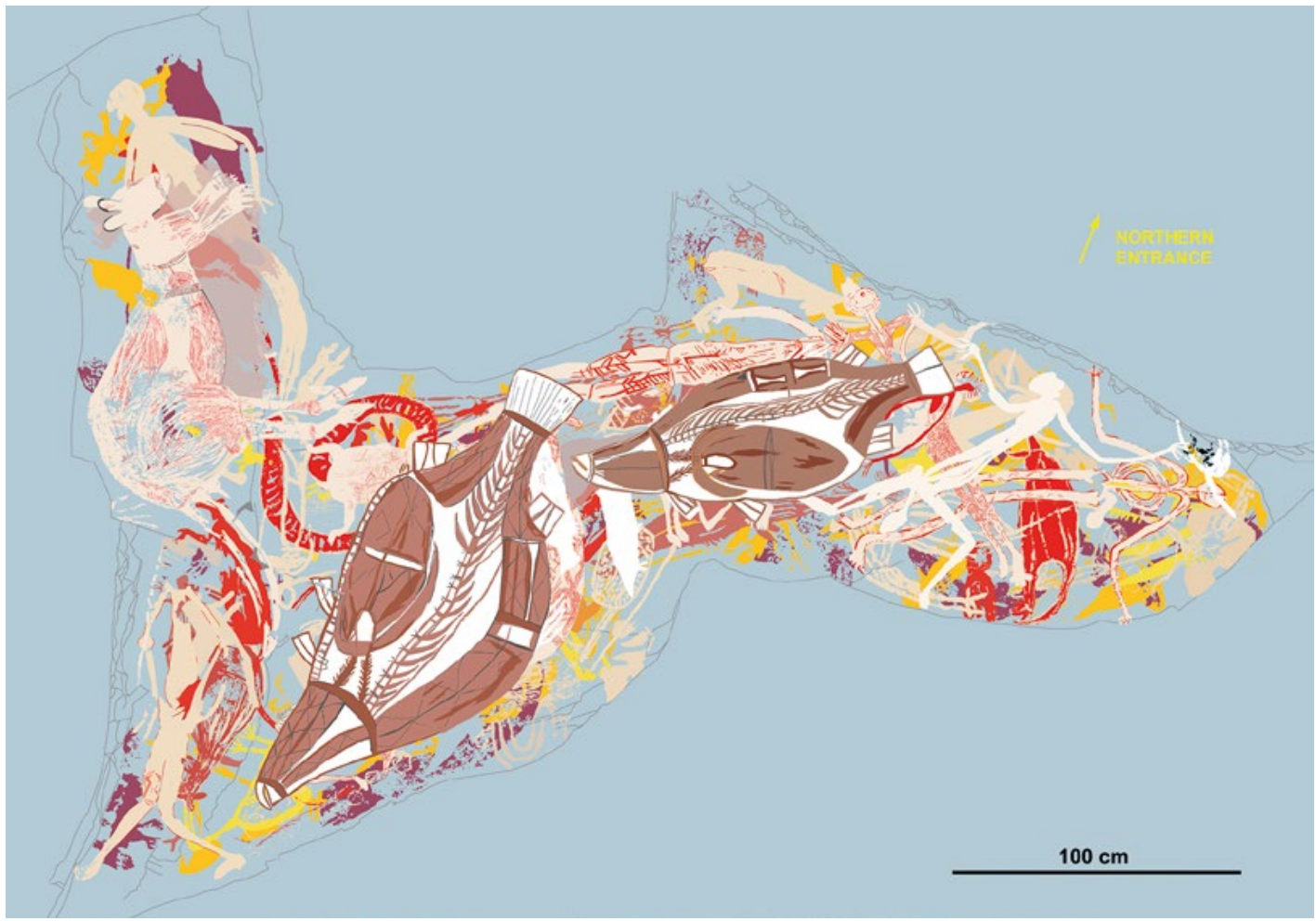

Figure 12.11 Photo-tracing of Panel H.

Source: Photo-tracing by Robert Gunn.

Motif H-122 is a beeswax figure radiocarbon dated to 1650->1910 cal AD (Wk-28101) (Table 12.1). The beeswax figure is overpainted by two white paintings (Figure 12.14), which are in turn overlain by a polychrome barramundi. Beeswax Image H-122 occurs midway within Phase $\mathrm{V}$ in the pattern of superimpositions. It is likely that other motifs within this phase, although in some cases produced prior to the beeswax figure, are roughly contemporaneous with each other due to similarities in their artistic traits.

As with Panel F1, there appears to have been little overall change in the range of motifs portrayed on Panel H over time (Table 12.6). Again, however, over the time period represented in Panel H, there has been a clear replacement of red and yellow by white pigment (Table 12.7). 


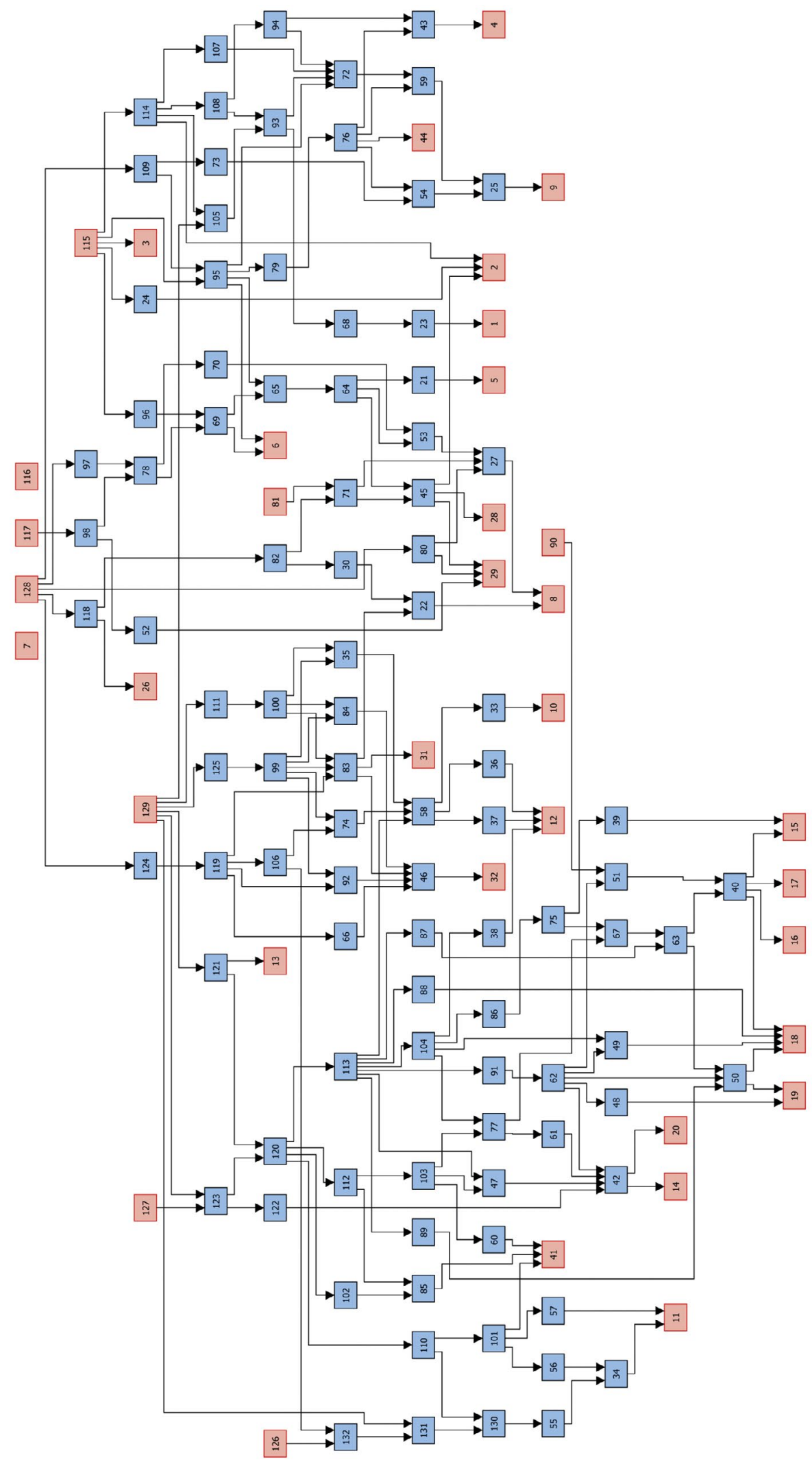

Figure 12.12 Harris Matrix of the Panel H superimpositions.

Red boxes = images at beginning or end of a superimposition sequence; blue boxes = images within a superimposition sequence. Source: Illustration by Robert Gunn. 


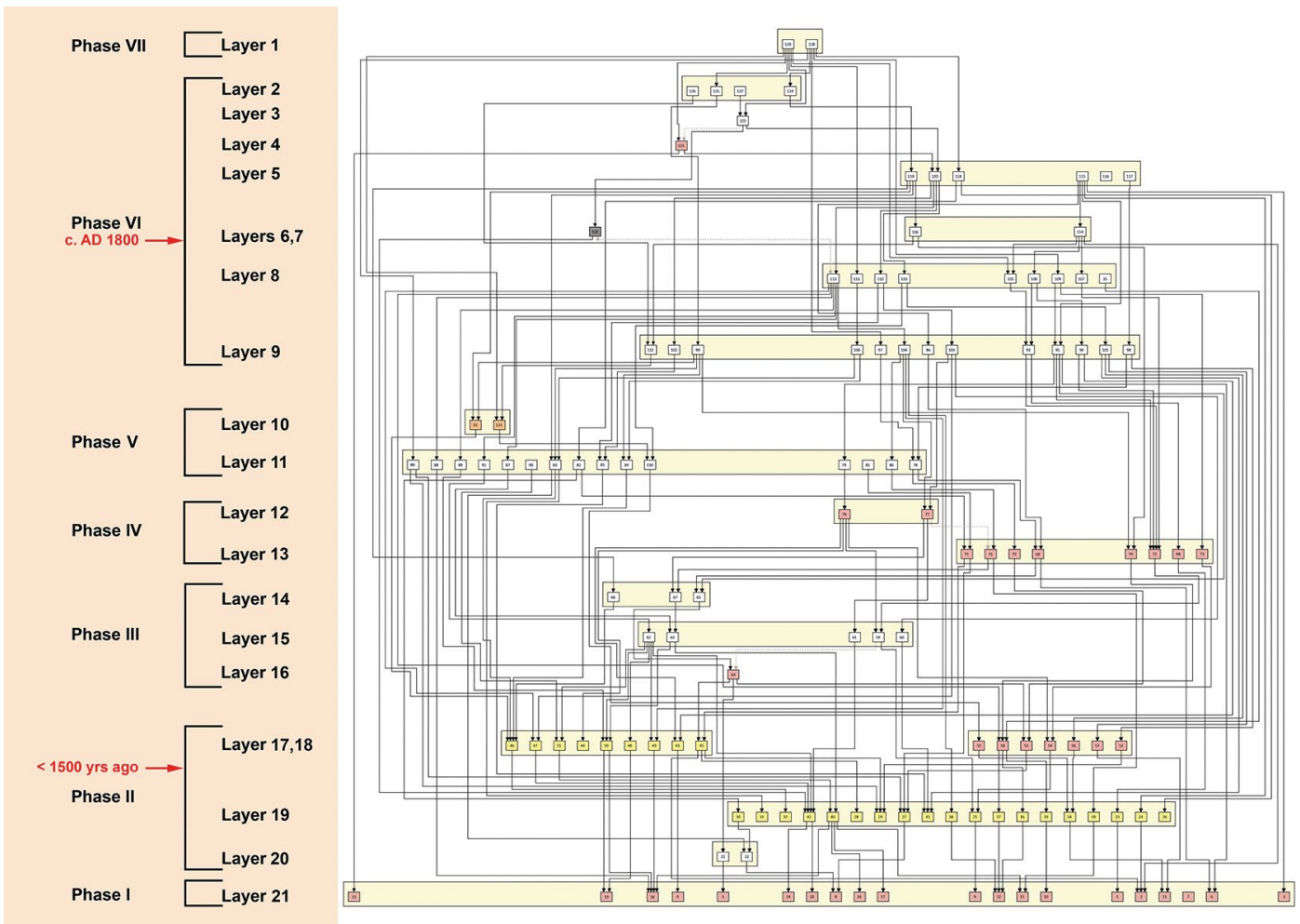

Figure 12.13 Interpretation and phasing of the Panel H Harris Matrix.

Source: Illustration by Robert Gunn.

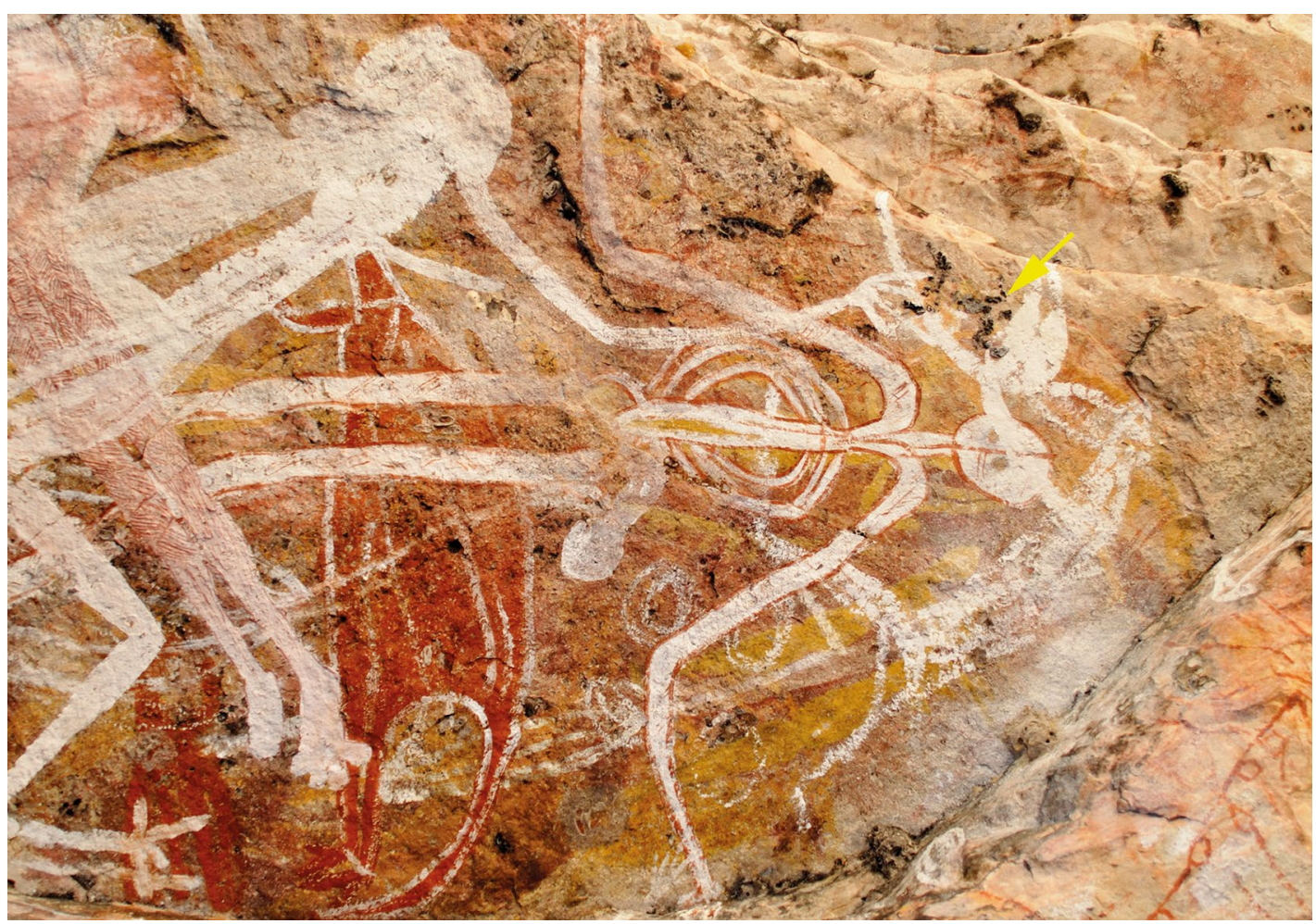

Figure 12.14 Beeswax Image H-122 (arrowed) dated to 1650->1910 cal AD.

Source: Photograph by Robert Gunn. 
Table 12.6 Panel H motifs by art phase (excluding fragments).

\begin{tabular}{|c|c|c|c|c|c|c|c|c|c|c|c|c|c|c|}
\hline \multirow{2}{*}{$\begin{array}{l}\text { Panel H } \\
\text { phase }\end{array}$} & \multicolumn{13}{|c|}{ Motif } & \multirow{2}{*}{$\begin{array}{c}\text { Total \# of } \\
\text { images }\end{array}$} \\
\hline & 픈 & 离 & 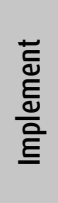 & $\stackrel{0}{\stackrel{\underline{E}}{\Xi}}$ & $\frac{\mathscr{\Xi}}{\check{\Sigma}}$ & 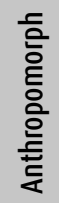 & 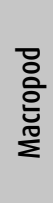 & 름 & $\begin{array}{l}\text { ్ㅠ } \\
\text { ㄲ }\end{array}$ & 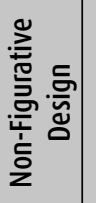 & 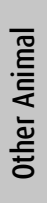 & 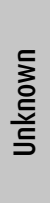 & 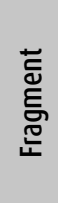 & \\
\hline $\mathrm{VI}$ & 2 & & & & & & & & & & & & & 2 \\
\hline $\mathrm{Vb}$ & 2 & 2 & & & & 4 & 2 & 1 & & 2 & & 2 & & 15 \\
\hline \multicolumn{15}{|c|}{ 1650->1910 cal AD (dated beeswax anthropomorph) } \\
\hline Va & & & 2 & 1 & & 9 & 2 & 1 & & & & 4 & 3 & 22 \\
\hline IV & & & & & & & 1 & & 2 & 9 & & 5 & & 17 \\
\hline III & & & 1 & 1 & 1 & & 3 & & & & & 4 & & 10 \\
\hline$\|$ & & & & & & 2 & 5 & 2 & 5 & 3 & 1 & 22 & 6 & 46 \\
\hline 1 & & & & & & & & & & 1 & 3 & 10 & 6 & 20 \\
\hline Total & 4 & 2 & 3 & 2 & 1 & 15 & 13 & 4 & 7 & 15 & 4 & 47 & 15 & 132 \\
\hline
\end{tabular}

Source: Authors' data.

Table 12.7 Panel H colours by art phase.

\begin{tabular}{|c|c|c|c|c|c|c|c|c|c|c|}
\hline \multirow{2}{*}{$\begin{array}{l}\text { Panel H } \\
\text { phase }\end{array}$} & \multicolumn{9}{|c|}{ Colour } & \multirow{2}{*}{$\begin{array}{r}\text { Total \# } 0 \\
\text { images }\end{array}$} \\
\hline & White+red+black & Pink & Black & White+red & Orange & White & Yellow & Red & Red+white & \\
\hline $\mathrm{VI}$ & 2 & & & & & & & & & 2 \\
\hline $\mathrm{Vb}$ & 1 & 2 & 1 & 3 & & 7 & & 1 & & 15 \\
\hline \multicolumn{11}{|c|}{ 1650->1910 cal AD (dated beeswax anthropomorph) } \\
\hline Va & & & & 5 & & 17 & & & & 22 \\
\hline IV & & & & & 2 & 15 & & & & 17 \\
\hline III & & & & & & & & 8 & 2 & 10 \\
\hline II & & & & & & 7 & 28 & 11 & & 46 \\
\hline I & & & & & & & & 20 & & 20 \\
\hline
\end{tabular}

Source: Authors' data.

\section{Panel D}

Panel D is roughly triangular in shape, $4.8 \times 3.3 \mathrm{~m}$ in size and has at least 15 layers of superimposition involving all but one of its 66 images. The art is visually dominated by polychrome paintings of two large barramundi and a range of smaller bichrome fish (Figure 12.15). These fish paintings are the most recent art on the panel. The largest motif here (Image D-48), however, is that of a horse $(4.4 \times 2.9 \mathrm{~m}$; Figure 12.16$)$ that underlies 17 paintings in five layers. Horses first entered the plateau in $1845 \mathrm{AD}$ (Leichhardt 1847). Consequently, all of the motifs overlying the horse painting are less than 170 years old. These overlying images include two fish in a Jawoyn $\mathrm{X}$-ray convention, six fish in X-ray conventions common to the north of Jawoyn Country and three 'Jawoyn Lady' paintings (see Gunn 1992:180). Interpretation of the Harris Matrix (Figures 12.17 and 12.18) divides the art into four phases, with the horse motif occurring midway through Phase III (Table 12.8). 
Table 12.8 Summary of the Panel $D$ art phases.

\begin{tabular}{|c|c|c|c|c|c|}
\hline Panel D phase & \# of layers & \# of images & Techniques & Major colours & Major motifs \\
\hline IV & 2 & 8 & $p$ & $\begin{array}{l}\text { white+red+black, white+red+purple, } \\
\text { white+red+yellow, white+red, } \\
\text { yellow+red }\end{array}$ & $\begin{array}{l}\text { X-ray, polychrome and } \\
\text { bichrome fish }\end{array}$ \\
\hline $\mathrm{IIIb}$ & 4 & 10 & $p$ & white+red, pink, white+red+grey & $\begin{array}{l}\text { Bichrome } \\
\text { anthropomorphs; } \\
\text { Pink fragments; } \\
\text { Polychrome horse }\end{array}$ \\
\hline \multicolumn{6}{|l|}{ AD 1845} \\
\hline Illa & 6 & 26 & $p$ & $\begin{array}{l}\text { white, white+red, red, cream, } \\
\text { cream+red }\end{array}$ & $\begin{array}{l}\text { Bichrome macropods, } \\
\text { bird, fish, turtle; } \\
\text { Solid white or cream } \\
\text { anthropomorph, birds, } \\
\text { macropods, hand stencils }\end{array}$ \\
\hline II & 2 & 13 & $P$ & red, red+white, black & $\begin{array}{l}\text { Red-striped macropod, } \\
\text { fragments of pigment art }\end{array}$ \\
\hline I & 1 & 9 & $p$ & yellow & $\begin{array}{l}\text { Solid yellow } \\
\text { anthropomorphs; } \\
\text { Yellow linear } \\
\text { anthropomorph; } \\
\text { Fragments of pigment art }\end{array}$ \\
\hline
\end{tabular}

Source: Authors' data.

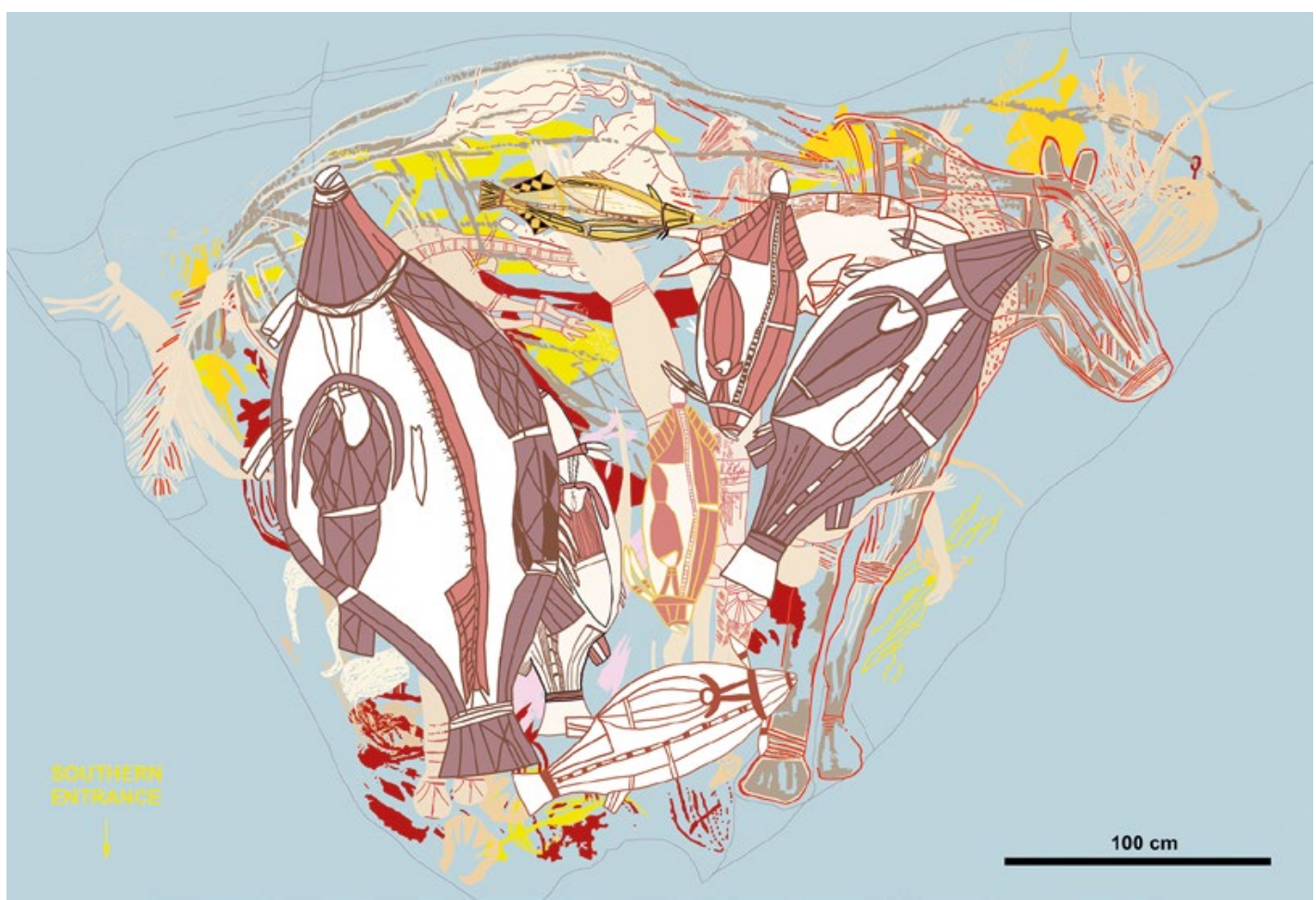

Figure 12.15 Photo-tracing of Panel D.

Source: Photo-tracing by Robert Gunn. 


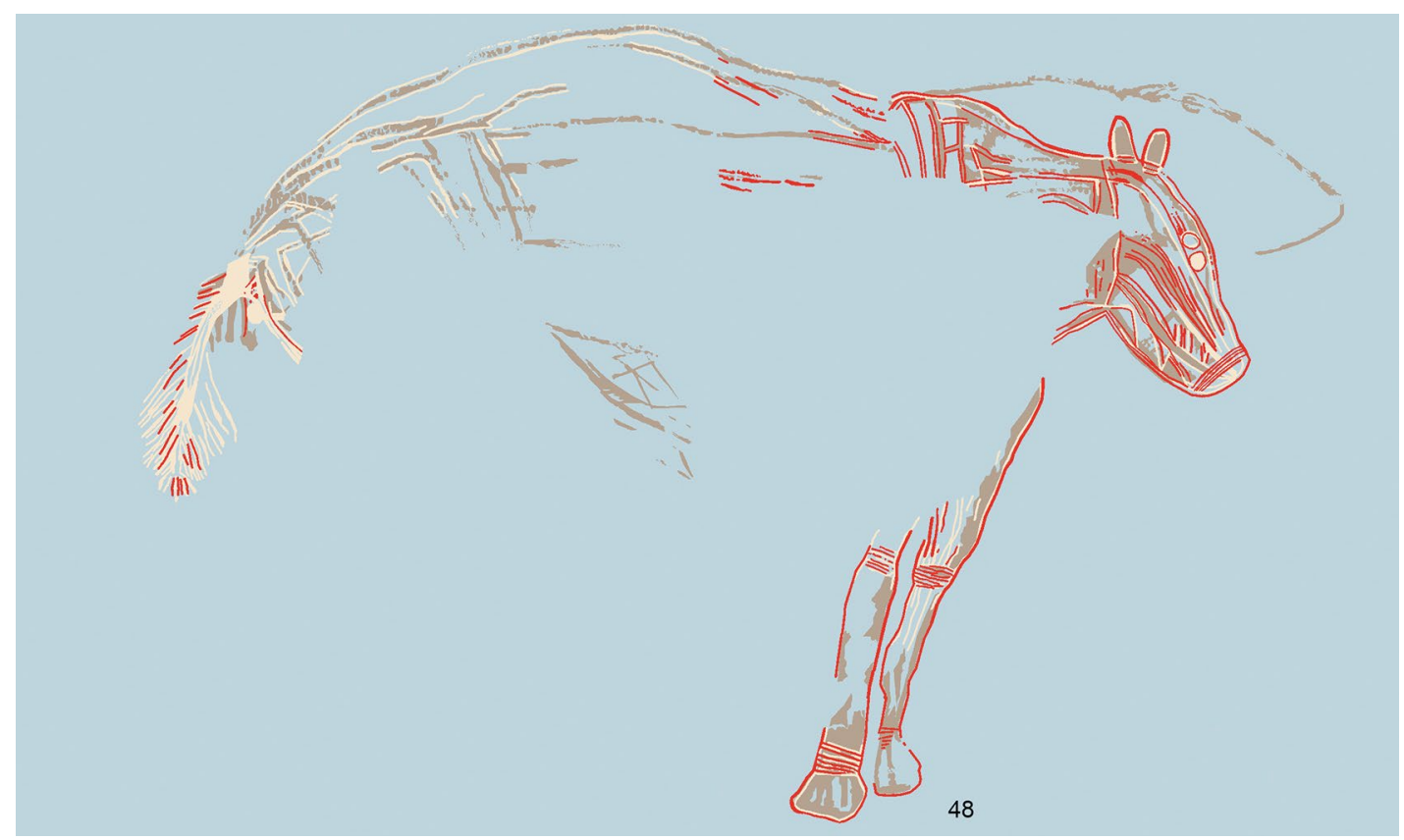

Figure 12.16 Horse image D-48, likely to represent a horse of the Leichhardt expedition in 1845 (see Chapter 9).

Source: Photo-tracing by Robert Gunn.

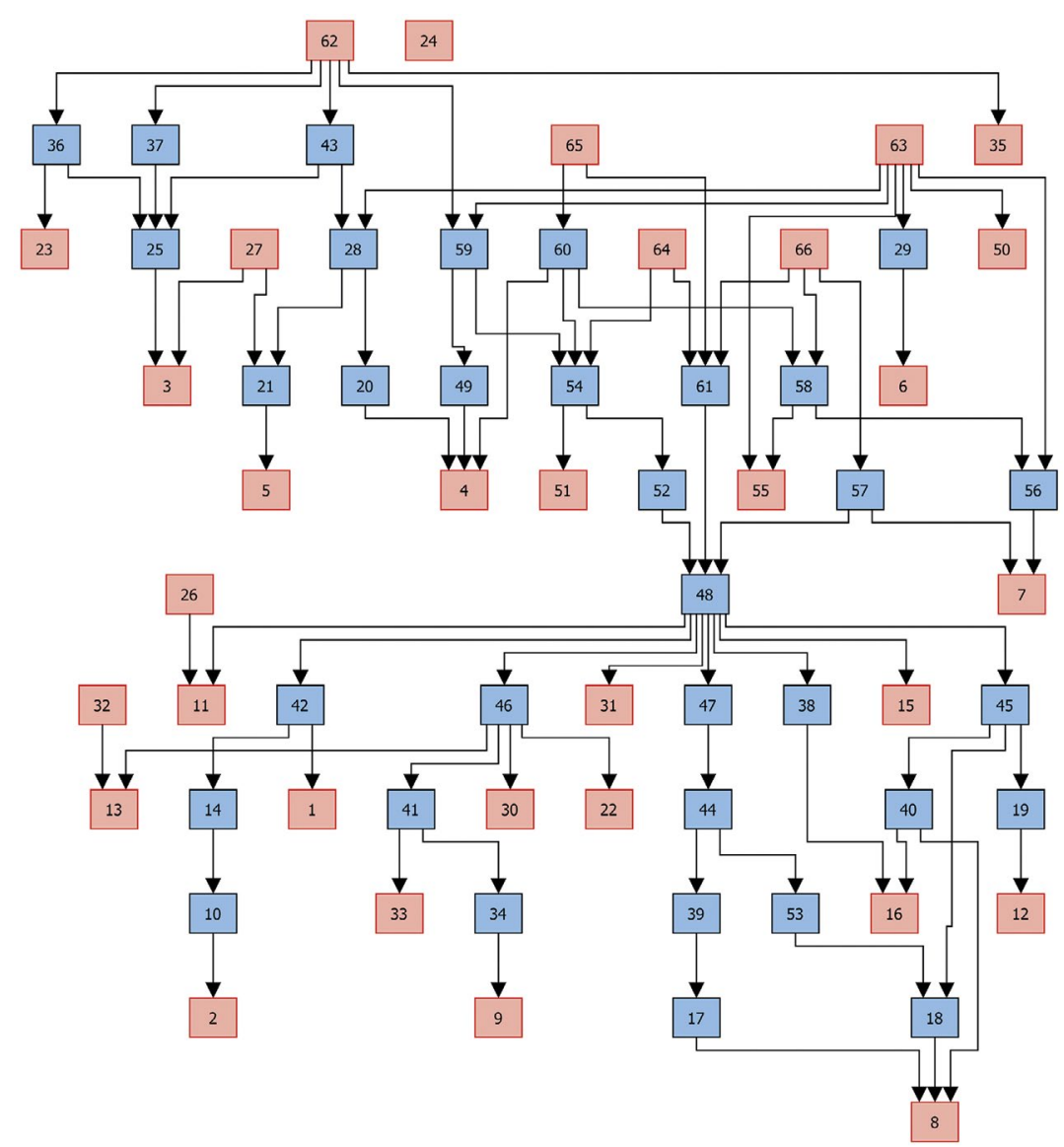

Figure 12.17 Harris Matrix of the Panel D superimpositions.

Red boxes = images at beginning or end of a superimposition sequence; blue boxes = images within a superimposition sequence. Source: Illustration by Robert Gunn. 

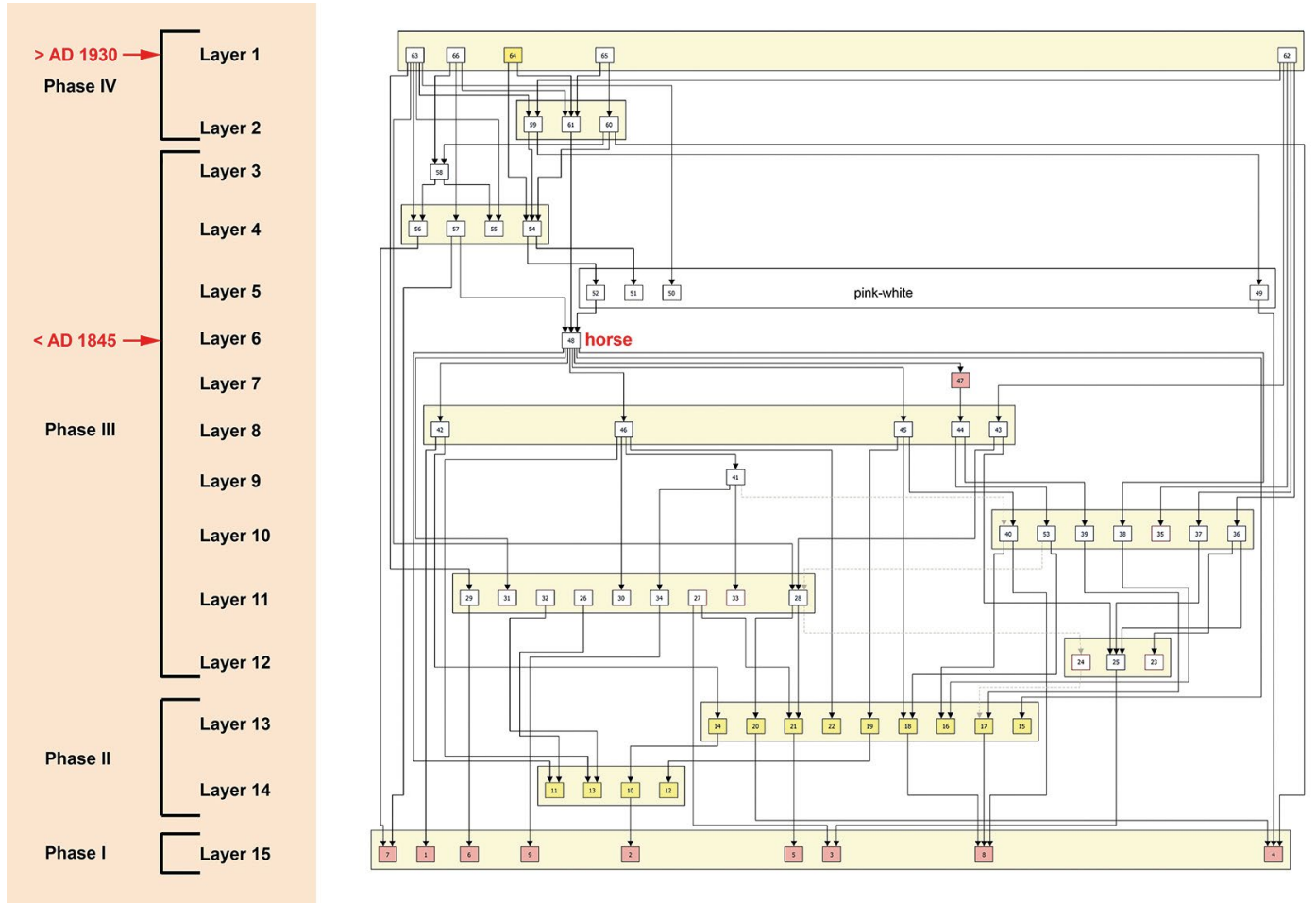

Figure 12.18 Interpretation and phasing of the Panel D Harris Matrix.

Source: Illustration by Robert Gunn.

The greater number of images in the upper layers of Panel D, however, cannot be seen as representing a period of flowering artistic activity. The reason for this is that the large size of, and density of pigment on, the polychrome fish mean that large areas that were probably decorated during earlier phases cannot now be seen. Hence, motif counts for these earlier phases are unlikely to be representative of the actual numbers of artworks produced.

From what is observable, and consistent with the other panels already described, there appears to have been little overall change in the range of motifs portrayed over time in Panel D (Table 12.9). In common with Panel H, however, Panel D shows a clear trend for the replacement of red and yellow pigments with white-based paintings around or shortly before $1845 \mathrm{AD}$ (Table 12.10).

Table 12.9 Panel $D$ motifs by art phase.

\begin{tabular}{|l|c|c|c|c|c|c|c|c|c|c|}
\hline $\begin{array}{l}\text { Panel D } \\
\text { phase }\end{array}$ & \multicolumn{2}{|c|}{ Motif Type } & Total \# of \\
images \\
\hline IV & Fish & Anthropomorph & Macropod & $\begin{array}{c}\text { Non-figurative } \\
\text { design }\end{array}$ & Turtle & Hand & Other & Horse & Fragment & \\
\hline IIIb & 8 & & & & & & & & & 8 \\
\hline 1845 AD & 3 & & & & & & 1 & 6 & 10 \\
\hline IIIla & 1 & 2 & 6 & 3 & 2 & 2 & 10 & & & 26 \\
\hline II & & 2 & & 1 & & & 2 & & 8 & 13 \\
\hline I & & & 1 & 1 & & & & & 7 & 9 \\
\hline Total & 9 & 7 & 7 & 5 & 2 & 2 & 12 & 1 & 21 & 66 \\
\hline
\end{tabular}

Source: Authors' data. 
Table 12.10 Panel $D$ colours by art phase.

\begin{tabular}{|c|c|c|c|c|c|c|c|c|c|c|}
\hline \multirow{2}{*}{$\begin{array}{l}\text { Panel D } \\
\text { phase }\end{array}$} & \multicolumn{9}{|c|}{ Colour } & \multirow{2}{*}{$\begin{array}{c}\text { Total \# of } \\
\text { images }\end{array}$} \\
\hline & Yellow+black & Polychrome & Cream+red & White+red & White & Pink & Cream & Yellow & Red & \\
\hline IV & 1 & 5 & & 2 & & & & & & 8 \\
\hline $\mathrm{IIIb}$ & & 1 & & 3 & 2 & 4 & & & & 10 \\
\hline \multicolumn{11}{|l|}{1845 AD } \\
\hline Illa & & & 3 & 6 & 13 & & 3 & & 1 & 26 \\
\hline II & & & & & & & & 13 & & 13 \\
\hline 1 & & & & & & & & & 9 & 9 \\
\hline Total & 1 & 6 & 3 & 11 & 15 & 4 & 3 & 13 & 10 & 66 \\
\hline
\end{tabular}

'Polychrome' refers to the use of three or more colours in a single image.

Source: Authors' data.

\section{Discussion}

Patterns of superimposition can be compared across the three panels by cross-correlating common artistic traits within individual phases. Given that some layers within some phases have been radiocarbon dated, we can assign absolute ages to those phases. The phases can thus be grouped into three chronological periods: 1) older than $1430 \mathrm{cal} A D$; 2) within the period 1430-1640 cal AD; and 3) $1640 \mathrm{cal} \mathrm{AD} \mathrm{-} 1953 \mathrm{AD}$ (Table 12.11). As painting appears to have ceased at Nawarla Gabarnmang around 1930 AD (Gunn et al. 2012; see also Chapter 9, this volume), the most recent period can be contained within a 290-year period, from $1640 \mathrm{cal}$ AD to $1930 \mathrm{AD}$. No age for the underlying and oldest art on these panels is known, and hence the starting date and depth for the earliest time period is unknown (but see Chapter 11).

Table 12.11 Cross-correlation of panel phases and time periods.

\begin{tabular}{|l|c|c|c|}
\hline Time period & Panel F1 & Panel H & Panel D \\
\hline 1640-1930 cal AD & Vla \& VIb & VI & IV \\
\cline { 2 - 4 } & & Va \& Vb & \\
\hline \multirow{3}{*}{$1430-1640 \mathrm{cal}$ AD } & V & & \\
\cline { 2 - 4 } & IV IIIb \\
\cline { 2 - 4 } & III & IV & \\
\cline { 2 - 4 } & II & III & II \\
\hline Pre-1430 cal AD & I & II & I \\
\cline { 2 - 4 } & & I & \\
\hline
\end{tabular}

Source: Authors' data.

Therefore, the three chronological Periods for Panels D, F1 and H are:

1. Recent: $1640 \mathrm{cal}$ AD - $1930 \mathrm{AD}$, with a sub-group from Panel D assigned to the time frame 1845-1930 AD by the horse depiction.

2. Second: $1430-1640 \mathrm{cal}$ AD.

3. First: Older than $1430 \mathrm{cal} \mathrm{AD.}$ 
Comparison of the art over these three Periods (Tables 12.12-12.13; Figures 12.19-12.23) indicates that:

- Polychrome paintings, including those incorporating an X-ray convention more commonly found in northerly parts of Arnhem Land (e.g. Figure 12.24), occur only in the Recent Period. All probably date to a time after $1845 \mathrm{AD}$ and so are less than 170 years old.

- Anthropomorphs and macropods, painted in white with delicate red infill, became prominent during the Recent Period, most probably after around $1640 \mathrm{cal}$ AD.

- The proportion of anthropomorphs and macropods increased in the Recent Period (after $1640 \mathrm{cal}$ AD) relative to earlier Periods.

- The range of motifs increased during the Second Period and continued into the Recent Period.

- Fish and non-figurative designs became more prominent during the Second and Recent Periods.

- Most white motifs occur during the Second and Recent Periods, with a marked increase in white-based paintings (white, white-and-red bichromes and polychromes) during the Recent Period (72 per cent of images, compared with 29 per cent in the Second Period and 7 per cent in the First).

- The use of red and red-based (red-and-white bichromes) motifs declines notably after the beginning of the Recent Period (c. $1640 \mathrm{cal} \mathrm{BP}$ ).

Table 12.12 Motifs by cross-correlated time periods (total \# of images $=324$ ).

\begin{tabular}{|c|c|c|c|c|c|c|c|c|c|c|c|c|c|c|}
\hline \multirow[t]{2}{*}{ Time period } & \multicolumn{13}{|c|}{ Motif } & \multirow{2}{*}{$\begin{array}{c}\text { Total \# of } \\
\text { images }\end{array}$} \\
\hline & 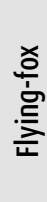 & : & $\stackrel{0}{\stackrel{ \pm}{\Xi}}$ & $\overline{\underline{\underline{4}}}$ & 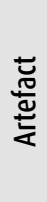 & 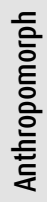 & 总 & $\begin{array}{l}\text { 음 } \\
\text { 은 } \\
\text { 이 }\end{array}$ & 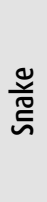 & 릉 & 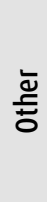 & 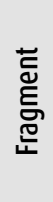 & Е్ & \\
\hline 1640-1930 cal AD & 3 & 1 & 3 & 14 & 6 & 26 & 19 & 14 & 3 & 2 & 23 & 9 & & 123 \\
\hline 1430-1640 cal AD & & 1 & 1 & 15 & 9 & 8 & 15 & 6 & 2 & & 22 & 3 & 2 & 84 \\
\hline Pre-1430 cal AD & & & & & & 7 & 9 & 6 & 1 & 2 & 47 & 45 & & 117 \\
\hline
\end{tabular}

Source: Authors' data.

Table 12.13 Colours of images by cross-correlated time periods (total \# of images $=324$ ).

\begin{tabular}{|c|c|c|c|c|c|c|c|c|c|c|c|c|c|c|}
\hline \multirow[t]{2}{*}{ Time period } & \multicolumn{13}{|c|}{ Colour } & \multirow{2}{*}{$\begin{array}{c}\text { Total \# of } \\
\text { images }\end{array}$} \\
\hline & 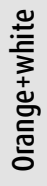 & 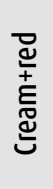 & E్ & 前 & 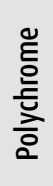 & 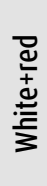 & & ¿্ׁ & $\frac{3}{\overline{0}}$ & $\frac{\text { 并 }}{\infty}$ & $\begin{array}{l}\text { 인 } \\
\text { 京 } \\
\text { 은 }\end{array}$ & $\begin{array}{l}\text { ॅั } \\
\text { 휴 }\end{array}$ & 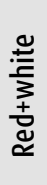 & \\
\hline 1640-1930 cal BP & 1 & 3 & 3 & 6 & 9 & 26 & 54 & 8 & 7 & 5 & 1 & & & 123 \\
\hline 1430-1640 cal BP & & & & & & 1 & 23 & 42 & & 4 & & 8 & 6 & 84 \\
\hline Pre-1430 cal BP & & & & & & & 8 & 58 & 46 & & 1 & & 4 & 117 \\
\hline
\end{tabular}

Source: Authors' data. 


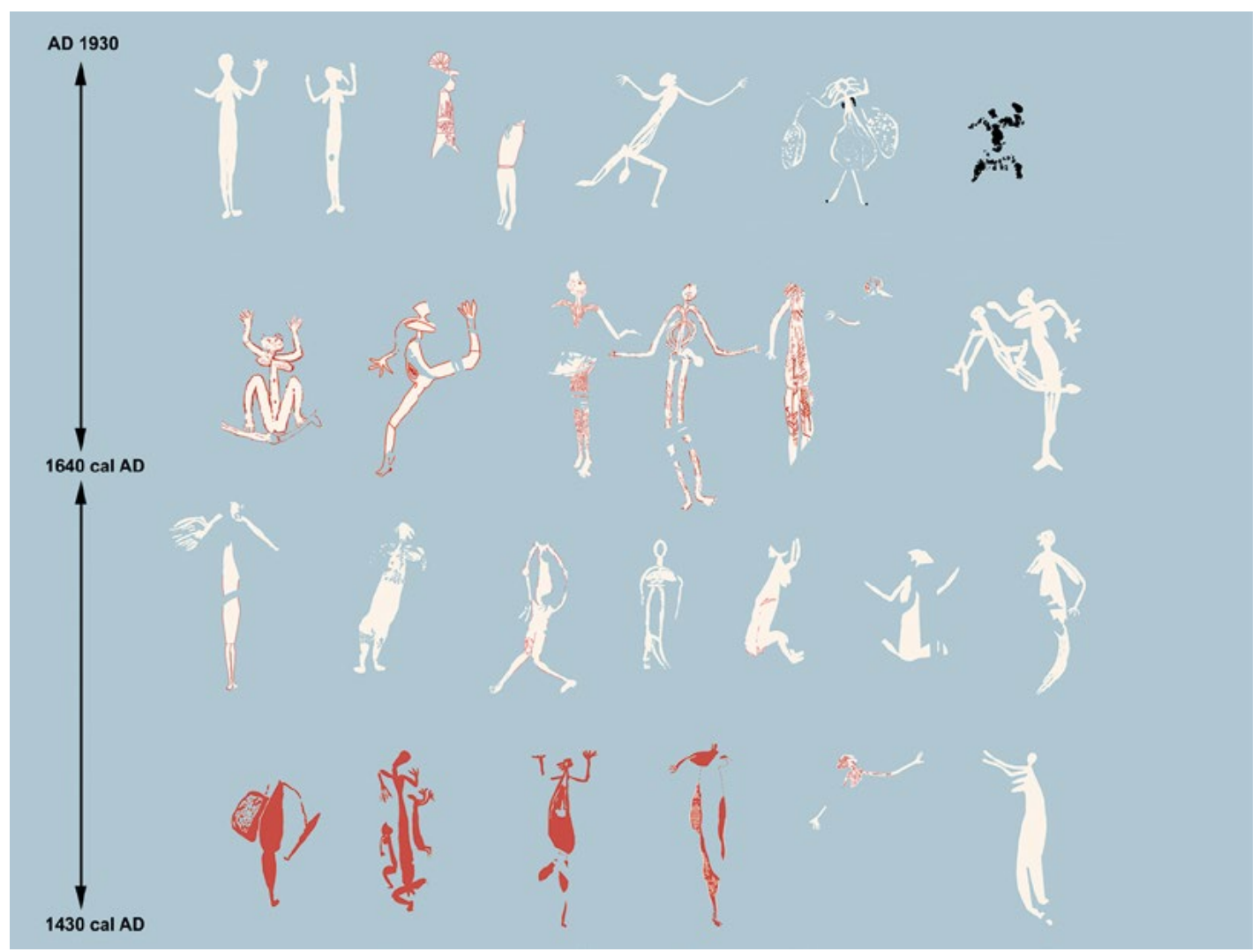

Figure 12.19 Anthropomorphs produced after $1430 \mathrm{cal}$ AD. Beeswax pellets and beeswax figures shown in black.

Source: Photo-tracing by Robert Gunn.

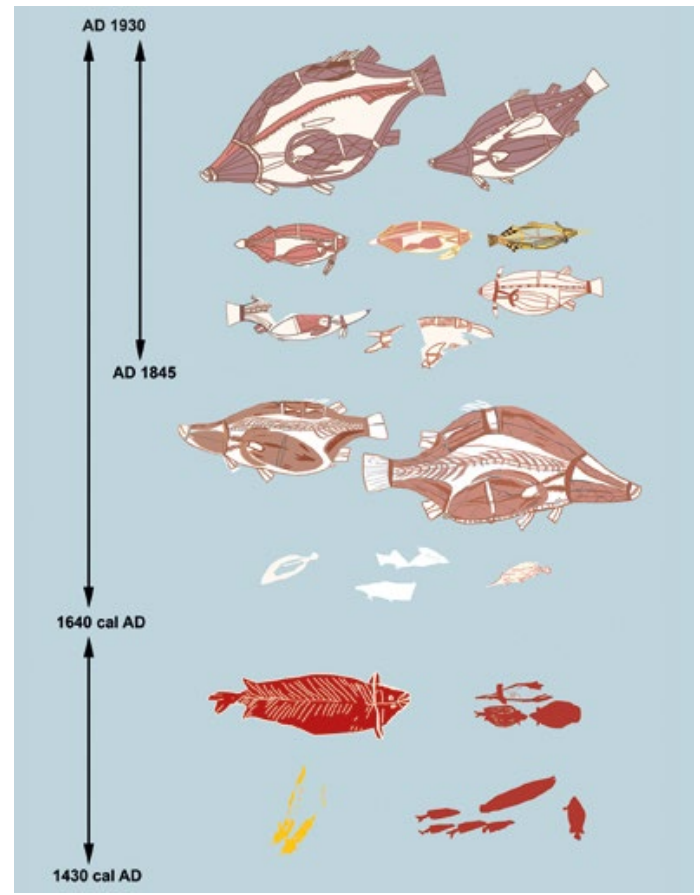

Figure 12.20 Fish images depicted after 1430 cal AD.

Source: Photo-tracing by Robert Gunn.

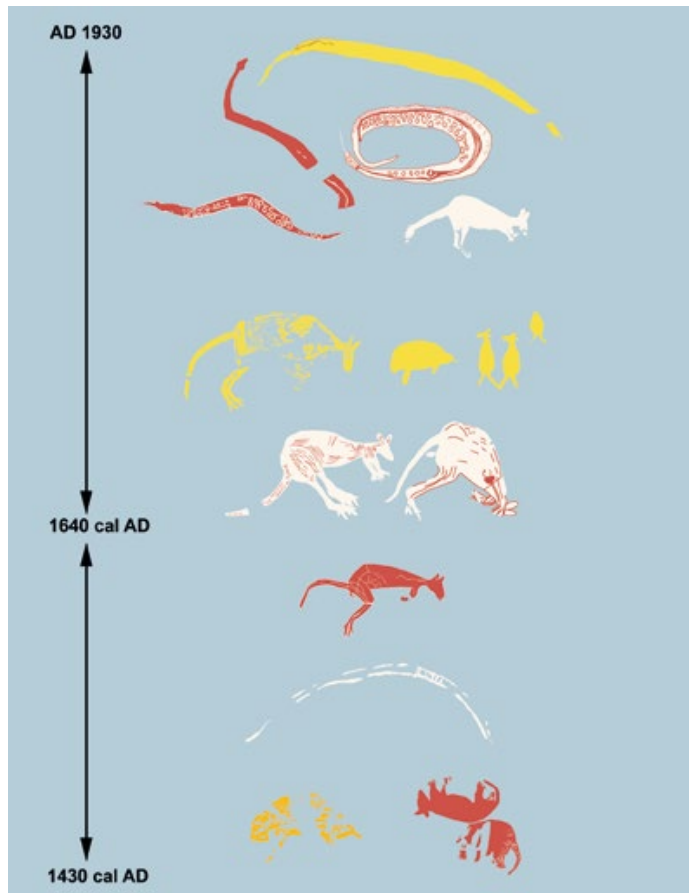

Figure 12.21 0ther faunal images depicted after 1430 cal $A D$.

Source: Photo-tracing by Robert Gunn. 


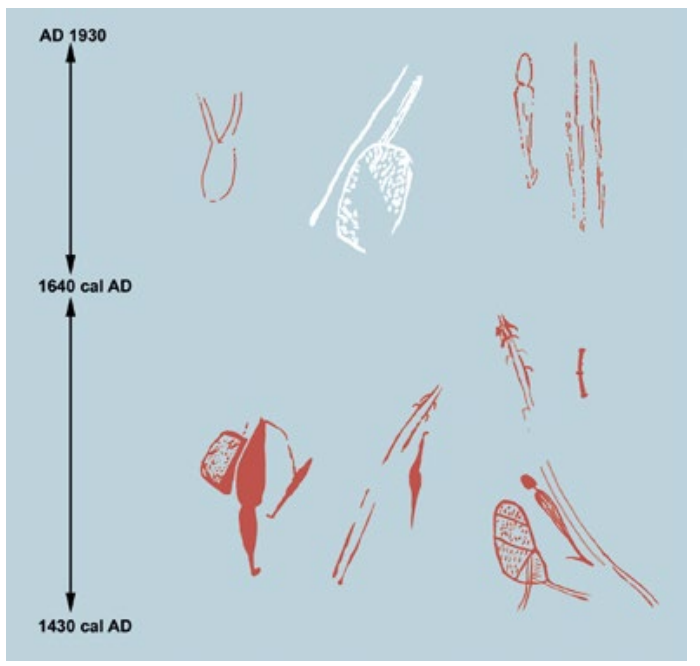

Figure 12.22 Implements depicted after 1430 cal AD.

Source: Photo-tracing by Robert Gunn.

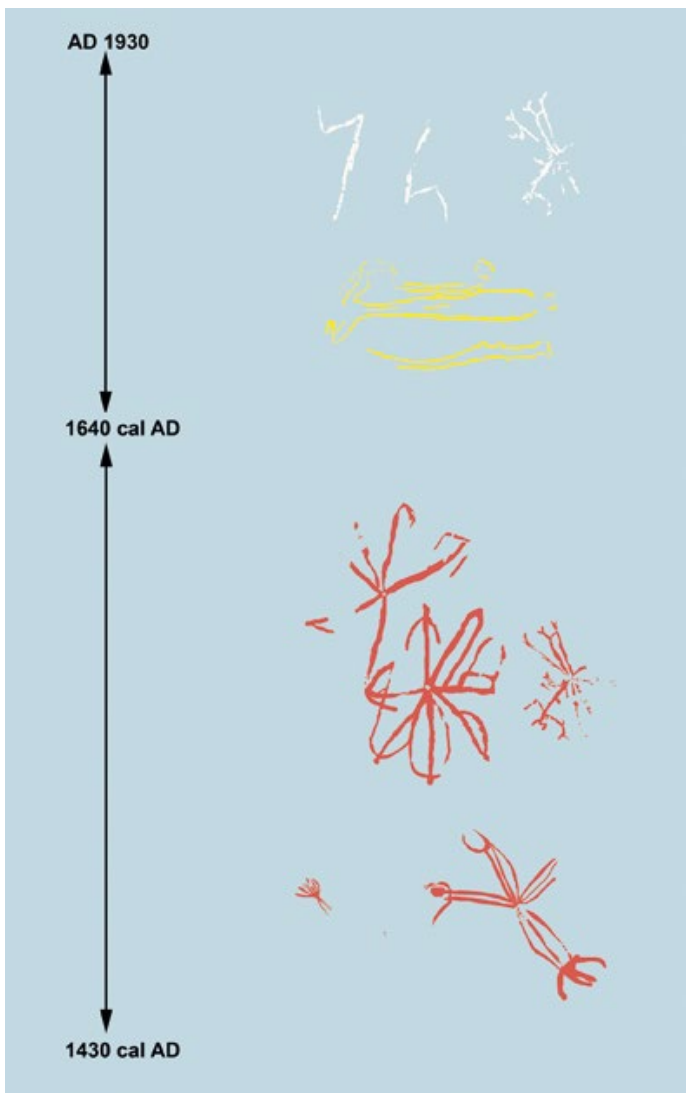

Figure 12.23 Non-figurative designs depicted after $1430 \mathrm{cal} A D$.

Source: Photo-tracing by Robert Gunn.
The art of Panels D, F1 and $\mathrm{H}$ have a number of changes in the use of colours and motifs over the period from pre- $1430 \mathrm{cal}$ AD times to $1930 \mathrm{AD}$. These changes appear to have been gradual, rather than occurring together as a single 'package' over a short period of time; the changes do not represent an abrupt and dramatic transformation of the overall repertoire. These results show:

- The specific impetuses behind the Recent Period art - cultural beliefs, understandings and codes relating to particular artistic practices - were also restricted to this period of time, the past 350-400 years.

- The time frame represented by the Recent Period is comparable with Chaloupka's (1993:191) 'Contact period', which he proposed began around 300 years ago, a period of cultural activity coincident first with the arrival of Macassans and then Europeans, Chinese and other outsiders.

- New 'traditional' styles such as polychrome X-ray fish and 'Jawoyn Lady' motifs (Figures 12.24 and 12.25; see also Chapters 11 and 13) developed during the Recent Period. These new styles contrasted with the stylistic conventions of the previous art periods when paintings were restricted to monochromes and bichromes and no female figures had achieved the high numbers, prominent positioning and wide distribution of the 'Jawoyn Lady' that became common in Jawoyn Country during the Recent Period (Gunn 1992:180). Chaloupka also pointed out, as we have also found, that 'stylistic conventions and painting techniques of the previous styles continued to be used' (Chaloupka 1993:191).

Overall, these results support Taçon's (1989b:318) finding: 'The most recent period of rock painting in Western Arnhem Land was one of great diversity and elaboration. It differs from earlier periods in terms of subject matter, form, use of colour and symbolic content'. His suggestion that most X-ray art was produced over the past 1500 to 300 years (Taçon 1989b:318, 330) may have unduly stretched 
out the chronology of this art form. We have found it only during the last 300 years and it is possible that X-ray art is younger in the southern half of the Arnhem Land plateau, which includes Nawarla Gabarnmang, than in the north.

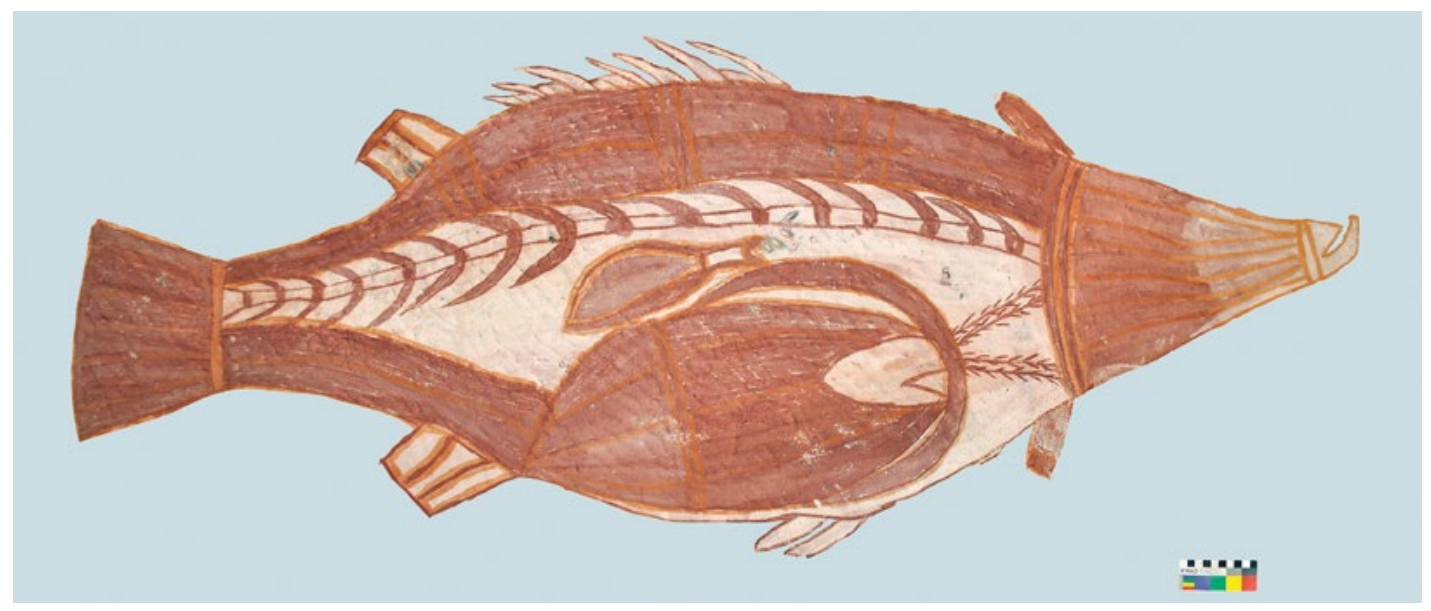

Figure 12.24 Polychrome X-ray fish (barramundi) from Panel E1. Scale $10 \mathrm{~cm}$.

Source: Photo-illustration by Robert Gunn.

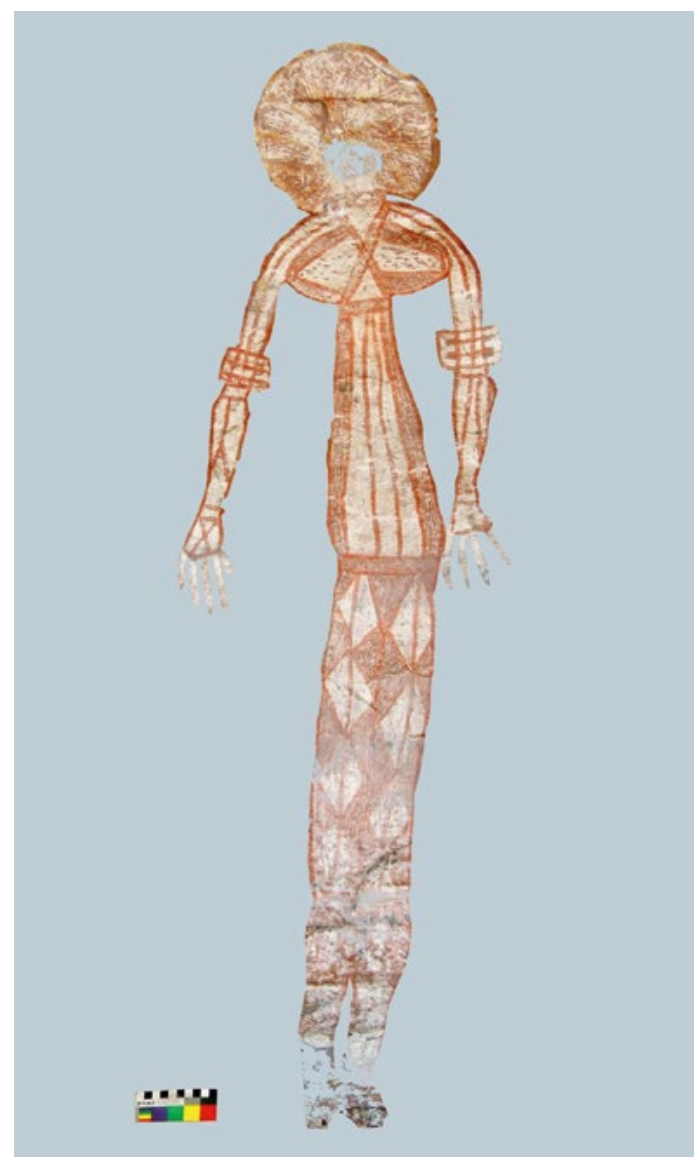

Figure 12.25 Bichrome 'Jawoyn Lady' from the nearby site A081-11. Scale $10 \mathrm{~cm}$.

Source: Photo-illustration by Robert Gunn.
A further implication of our results is that Taçon's concept of 'rainbowness', symbolised by bright combinations of colour through hatching, cross-hatching and solid bands of pigment (Taçon 1989b:326, 1991:197), may also be a recent phenomenon. This, in turn, implies his proposed 'shift in religious orientation' (Taçon 1989b:330) was also relatively recent.

Alternatively, these results from Nawarla Gabarnmang may relate to local circumstances in southern parts of Arnhem Land only. They may indicate recent and in some ways restricted contacts with people from the north and their polychrome X-ray fish art. 


\section{Conclusion}

Analyses of these three large art panels at Nawarla Gabarnmang have provided a chronological sequence for its recent rock art: an initial change in the recent art within the time period 1430-1640 cal AD, during which time white pigment became more popular and the range of motifs increased; followed by a further transition from $1640 \mathrm{cal} \mathrm{AD}$ to $1930 \mathrm{AD}$, when red pigment became relatively seldom used and white monochrome and white-based bichrome and polychrome paintings became much more common. Since white pigment is known to survive less well, the increase in white art may be thought to result from differential preservation. The ceiling surfaces, however, are very well protected from the elements and from animal activity, so we see the primary cause for the changes in colours used, and in artistic styles, as cultural. Whether the decrease in the use of red pigment and increase in white pigment at Nawarla Gabarnmang signals changing access to pigment types, or pigment sources, and/or whether they indicate a change in the choice of colour use relate to their symbolic associations remains unknown. No sources of either red or white pigment are known anywhere within tens of kilometres of Nawarla Gabarnmang.

\section{Acknowledgements}

We thank Fiona Petchey (Waikato Radiocarbon Dating Laboratory) for converting the radiocarbon dates with $\mathrm{OxCal}$ and discussing the results. Leigh Douglas provided invaluable help with fieldwork and editorial comments. The late Bardayal Nadjamerrek and Peter Bolgay provided invaluable background information on the site and interpretations of the artwork. Our colleague Jean-Michel Geneste (Centre National de Préhistoire, France) also contributed to on-site discussions. Ray Whear (then of the Jawoyn Association) provided logistical support, and the work was supported by the Board of the Jawoyn Association. Thanks also to our pilots Chris Morgan and Darren Stockton. At Monash University, thanks to the Monash Indigenous Studies Centre for support. We thank the Australian Research Council for Linkage grant LP110200927 and Discovery Outstanding Research Award (DORA) Fellowship (to BD) DP130102514.

\section{References}

Bednarik, R.G. 2001. The taphonomy of beeswax figures. Rock Art Research 18:91-95.

Berndt, R.M. and C.H. Berndt 1977. The World of the First Australians. Ure Smith, Sydney.

Bronk Ramsey, C. 2013. OxCal Program v4.2.2. Radiocarbon Accelerator Unit, University of Oxford, Oxford.

Chaloupka, G. 1977. Aspects of the chronology and schematisation of two prehistoric sites on the Arnhem Land plateau. In P.J. Ucko (ed.), Form in Indigenous Art, pp. 243-259. Australian Institute of Aboriginal Studies, Canberra.

Chaloupka, G. 1984. From Paleo Art to Casual Paintings. Monograph Series 1. Northern Territory Museum of Arts and Sciences, Darwin.

Chaloupka, G. 1985. Chronological sequence of Arnhem Land plateau rock art. In R. Jones (ed.), Archaeological research in Kakadu National Park, pp. 269-280. Special Publication 13. Australian National Parks and Wildlife Service, Canberra.

Chaloupka, G. 1993. Journey in Time: The World's Longest Continuing Art Tradition. Reed, Chatswood. 
Chippindale, C. and P.S.C. Taçon 1993. Two old painted panels from Kakadu: Variation and sequence in Arnhem Land rock-art. In J. Steinbring, A. Watchman, P. Faulstich and P.S.C. Taçon (eds.), Time and Space: Dating and Spatial Considerations in Rock-Art Research, pp. 32-56. Occasional AURA Publication 8. Australian Rock Art Research Association, Melbourne.

David, B., J.-M. Geneste, R.L. Whear, J.-J. Delannoy, M. Katherine, R.G. Gunn, C. Clarkson, H. Plisson, P. Lee, F. Petchey, C. Rowe, B. Barker, L. Lamb, W. Miller, S. Hoerle, D. James, E. Boche, K. Aplin, I.J. McNiven, T. Richards, A. Fairbairn and J. Matthews 2011. Nawarla Gabarnmang, a 45,185 \pm 910 cal BP site in Jawoyn Country, southwest Arnhem Land Plateau. Australian Archaeology 73:73-77.

Delannoy, J.-J., B. David, J.-M. Geneste, M. Katherine, B. Barker, R.L. Whear and R.G. Gunn 2013. The social construction of caves and rockshelters: Chauvet Cave (France) and Nawarla Gabarnmang (Australia). Antiquity 87:12-29. doi.org/10.1017/S0003598X00048596

Geneste, J.-M., B. David, H. Plisson, C. Clarkson, J.-J. Delannoy, F. Petchey and R. Whear 2010. Earliest evidence for ground-edge axes 35,400 \pm 410 cal BP from Jawoyn Country, Arnhem Land. Australian Archaeology 71:66-69. doi.org/10.1080/03122417.2010.11689385

Gunn, R.G. 1992. Bulajang - A reappraisal of the archaeology of an Aboriginal cult. In J. McDonald and I.P. Haskovec (eds), State of the Art, pp. 174-194. Occasional AURA Publication 6. Australian Rock Art Research Association, Melbourne.

Gunn, R.G. 2016. Art of the Ancestors: Spatial and Temporal Patterning in the Rock Art of Nawarla Gabarnmang, A Major Jawoyn Cultural Site on the Arnhem Land Plateau. Unpublished PhD thesis. Monash University, Clayton.

Gunn, R.G., R.L. Whear and L.C. Douglas 2012. Dating the present at Nawarla Gabarnmang: Time and function in the art of a major Jawoyn rock art and occupation site in western Arnhem Land. Australian Archaeology 75:55-65. doi.org/10.1080/03122417.2012.11681950

Haskovec, I.P. 1992. Mt Gilruth revisited. Archaeology in Oceania 27:61-74. doi.org/10.1002/j.18344453.1992.tb00285.x

Leichhardt, L. 1847. Journal of an Overland Expedition in Australia, from Moreton Bay to Port Essington, a Distance of Upwards of 3000 Miles, during the Years 1844-1845. T. and W. Boone, London. adc.library.usyd.edu.au/data-2/p00050.pdf. Accessed 13 February 2013.

Lewis, D. 1988. The Rock Paintings of Arnhem Land, Australia. BAR International Series 415. British Archaeological Reports, Oxford.

May, S.K., P.S.C. Taçon, D. Wesley and M. Travers 2010. Painting history: Indigenous observations and depictions of the 'Other' in northwestern Arnhem Land, Australia. Australian Archaeology 71:57-65. doi.org/10.1080/03122417.2010.11689384

Nelson, D.E. (ed.) 2000. The Beeswax Art of Northern Australia. CD publication. Simon Fraser University, Burnaby.

Reimer, P.J., E. Bard, A. Bayliss, J.W. Beck, P.G. Blackwell, C. Bronk Ramsey, C.E. Buck, H. Cheng, R.L. Edwards, M. Friedrich, P.M. Grootes, T.P. Guilderson, H. Haflidason, I. Hajdas, C. Hatté, T.J. Heaton, D.L. Hoffmann, A.G. Hogg, K.A. Hughen, K.F. Kaiser, B. Kromer, S.W. Manning, M. Niu R.W. Reimer, D.A. Richards, E.M. Scott, J.R. Southon, R.A. Staff, C.S.M. Turney and J. van der Plicht 2013. IntCal13 and Marine13 radiocarbon age calibration curves, 0-50 000 years cal BP. Radiocarbon 55 (4):1869-1887. doi.org/10.2458/azu_js_rc.55.16947

Stuiver, M. and P.J. Reimer 1993. Extended ${ }^{14} \mathrm{C}$ data base and revised CALIB $3.0{ }^{14} \mathrm{C}$ age calibration program. Radiocarbon 35:215-230. doi.org/10.1017/S0033822200013904 
Taçon, P.S.C. 1987. Internal-external: A re-evaluation of the 'X-ray' concept in western Arnhem Land rock art. Rock Art Research 4:36-50.

Taçon, P.S.C. 1989a. From Rainbow Snakes to 'X-Ray' Fish: The Nature of the Recent Rock Painting Tradition of Western Arnhem Land, Australia. Unpublished PhD thesis. The Australian National University, Canberra.

Taçon, P.S.C. 1989b. From the 'dreamtime' to the present: The changing role of Aboriginal rock painting in western Arnhem Land, Australia. Canadian Journal of Native Studies 1989:317-339.

Taçon, P.S.C. 1991. The power of stone: Symbolic aspects of stone use and tool development in western Arnhem Land, Australia. Antiquity 65:192-207. doi.org/10.1017/S0003598X00079655

Taçon, P.S.C. 1992. Somewhere over the Rainbow: An ethnographic and archaeological analysis of recent rock paintings of western Arnhem Land. In J. McDonald and I.P. Haskovec (eds), State of the Art, pp. 202-215. Occasional AURA Publication 6. Australian Rock Art Research Association, Melbourne.

Taçon, P.S.C. 1993. Regionalism in the recent rock art of western Arnhem Land, Northern Territory. Archaeology in Oceania 28:112-120. doi.org/10.1002/j.1834-4453.1993.tb00302.x

Taçon, P.S.C. and C. Chippindale 1994. Australia’s ancient warriors: Changing depictions of fighting in the rock art of Arnhem Land, (N.T.). Cambridge Archaeological Journal 4:211-248. doi.org/10.1017/ S0959774300001086

Taylor, L. 1996. Seeing the Inside: Bark Painting in Western Arnhem Land. Clarendon Press, Oxford.

Wesley, D. 2013. Firearms in rock art of Arnhem Land, Northern Territory, Australia. Rock Art Research $30: 235-247$. 
This text is taken from The Archaeology of Rock Art in Western Arnhem Land, Australia, edited by Bruno David, Paul Taçon, Jean-Jacques Delannoy and Jean-Michel Geneste, published 2017 by ANU Press, The Australian National University, Canberra, Australia.

dx.doi.org/10.22459/TA47.11.2017.12 